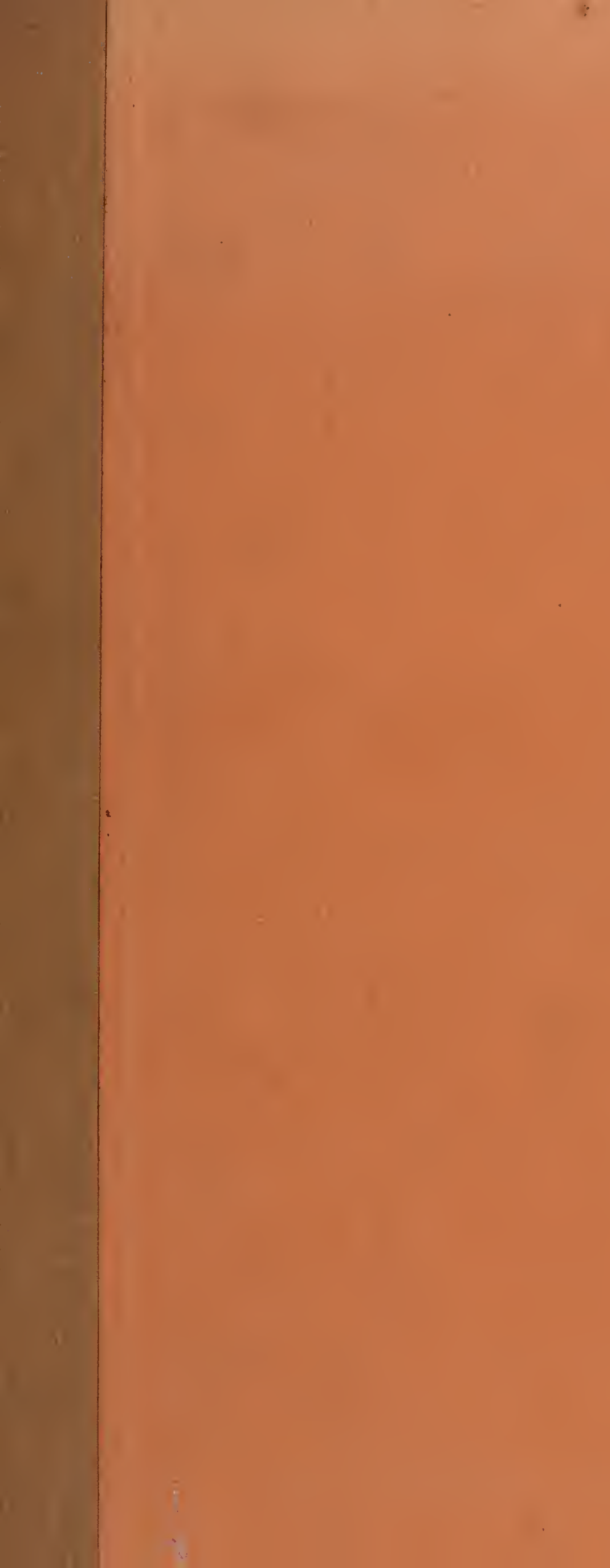




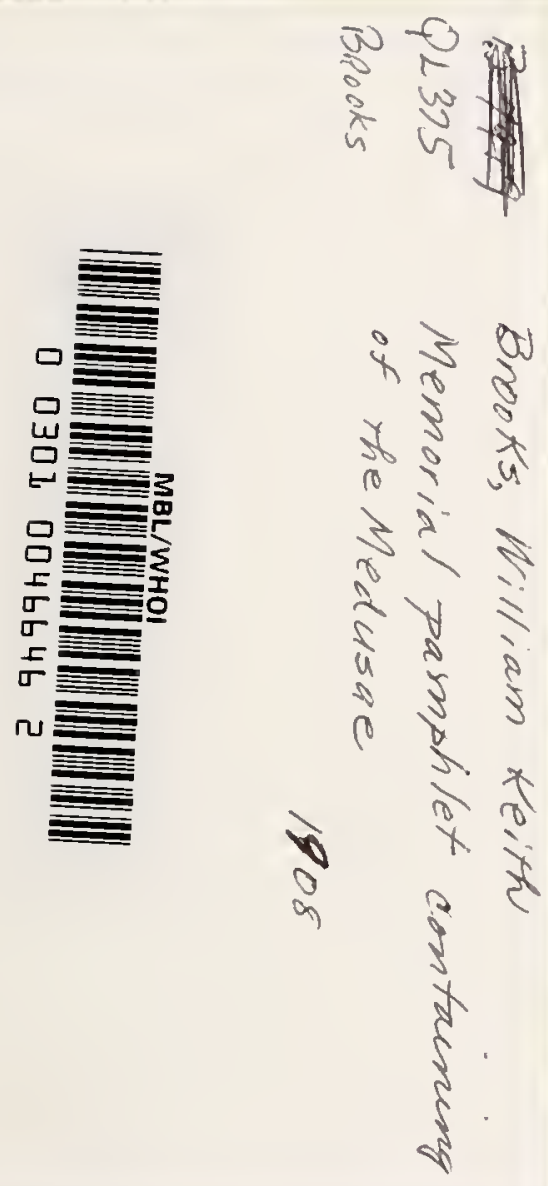



\section{MEMORIAL PAMPHLET}

\section{CONTAINING \\ CERTAIN DRAWINGS OF MEDUSAE}

MADE BY

The late Professor William KeITh Brooks,

of the Johns Hopkins University. 


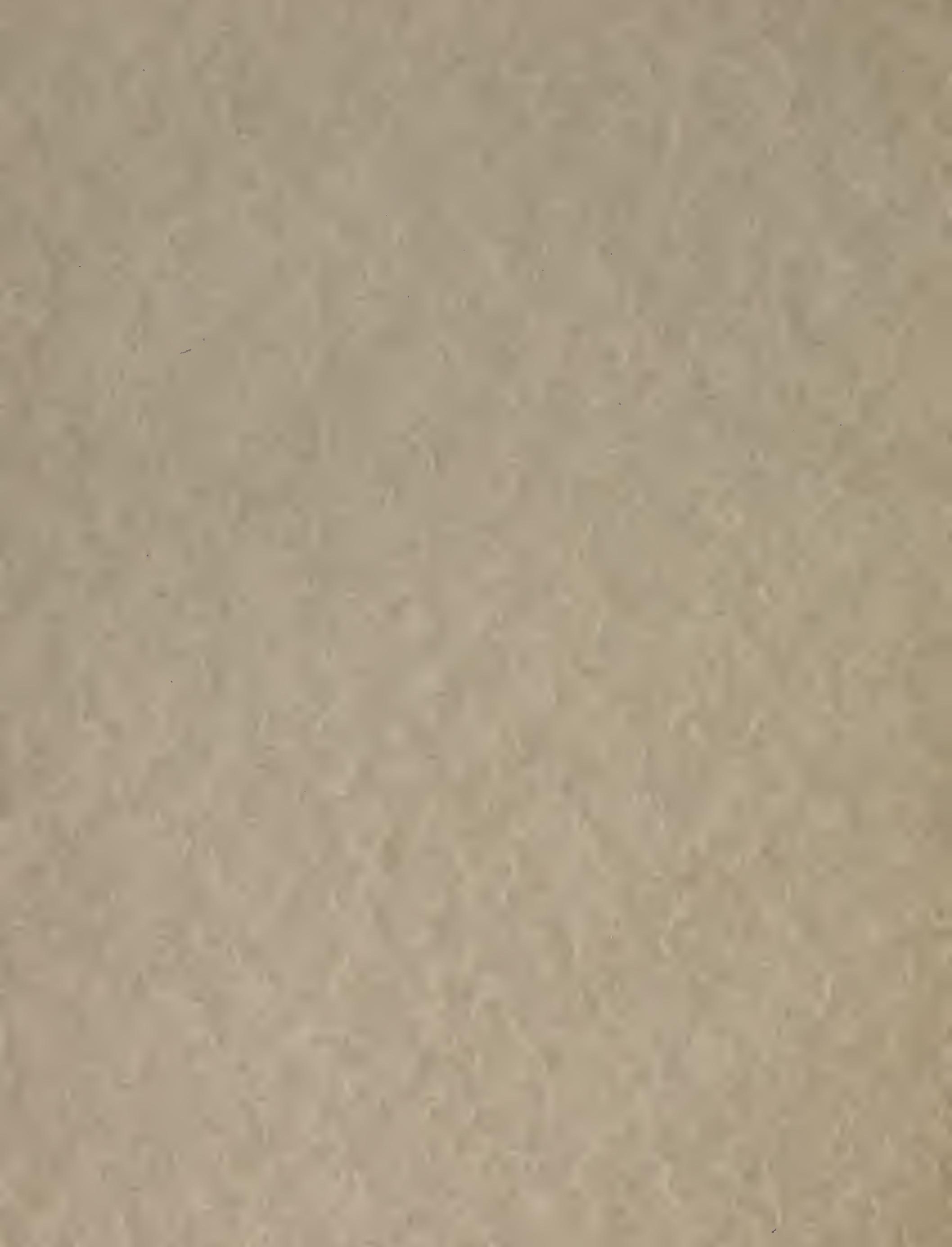




\section{MEMORIAL PAMPHLET \\ CONTAINING \\ CERTAIN DRAWINGS OF MEDUSAE \\ MADE BY}

The late Professor William Keith Brooks, of the Johns Hopkins University. 
NOTE.

This collection of drawings is extracted from the three volumes of Medusx of the World, by Alfred G. Mayer, to whom they were presented, for publication, either by Professor Brooks himself or by the Department of Biology of the Johns Hopkins University, after the death of l'rofessor Brooks in rgos.

It is hoped that by gathering into one publication the beatifully executed drawings of this faithful observer we may raise one more tribute of respect to his memory as a leader in research. 


\title{
DRAWINGS OF MEDUSAE
}

\author{
Made by the late Professor Williay K. Brooks.
}

Genus PODOCORYNE Sars, I846.

Podocoryne carnea Sars.

Synonyms of the European Form.

(?) Dismorphosa conchicola, P'HILIPpI, 1842, Archiv. für Naturgesch., Jahrg. 8, BJ. I, P. 37, taf. I, fig. 3 .

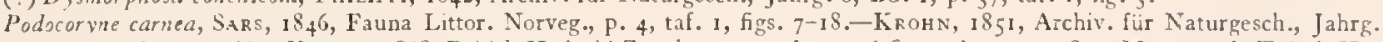
17, Bd. I, p. 266.-Hivcks, I 868, British Hydroid Zooph., p. 29, plate 5, 6 figs.-Alimas, i 871 , Monograpl Tubul. Hydroids, p. 349, plate 16, figs. 1-9.-DE VARENNe, I 882, Archiv. de Zool. Expér., tome 10, pp. 645, 674, 683, plate 33, figs. 6-15; plates $34,36-38 ; 1882$, Compt. rend. Paris, tome 94, p. 892 . - Weismans, 1883 , Sexualzellen bei den Hydromedusen, pp. 63-72, taf. 19, fign. I-13. -Browne, I 896, Proc. Zool. Soc. London, P. 463.-De Varknne, I 881 , Annals and Mag. Nat. Hist., ser. 5, vol.9, P. 134.-Hamane, 1882, Jena. Zeitschrift für Naturwissen., Bd.15, p.517, taf. 20, fign. I, 3, 4 (histology of hydroid).-JichFL1, I883, Morphol. Jahrb., Bd. 8, P. 621, taf. 27 (histology of the hydroid). -GFAlFFE, 1884, Arbeit. Zool. Inst. Wien, Bd. 5, p. 347.-Ishikaws, 1888, Zeit. für wissen. Zool., Bd. 47, p. 621, 6 fign. (origin of egg cells).-BEDot, 1905, Revue Suisse de Zool., tome 13, P. 103 (literature 1842-1850).-R1tchie, I907, Trans. Roy. Soc. Edinburgh, vol. 45 , p. 523 (from Cape Colony, South Africa).

Dysmor phosa carnea, Harckel, 1879 , Syst. der Medusen, p. 77.

Cyrois exigua, HaECKFL, Ibid., p. 634 .

Podocoryne hackelii, HaMann, i 882 , Jena. Zeit. fuir Naturwissen., Bd. 15, P. 519 (young stocks of $P$. carnea?).

(?) Podocorne conchicola (P'nilippi) in part, Hargit , 1904, Mitth. Zool. Station Neapel, Bd. 16, p. 581, fig. 26, taf. 22.

Synonyms of the American Representative.

Turritopsis nutricula, Agassiz, A., i 862, Proc. Boston Soc. Nat. Hist., vol.9, p. 97, figs. 22, 23; 1865, North Amer. Acal., P. 167, figs. 269, 270.-FEwkEs, 1881, Bull. Mus. Comp. Zool., vol. 8, P.153, plate 4, figs. 4, 7-10.

Calcydion formosum, Fewkes, $188_{2}$, Tull. M us. Comp. Zool., vol. 9. p. 294.

Polocoryne carnera, Bunting, 1894 , Journ. Morphol., vol. 9, p. 205, plate i1, fig. 68.-Levinsen, 1893 , Vid. Meddel. Nat. For. Kjöbenhavn (5), Bd. 4, p. 153.-HargitT, 1904, Bull. U. S. Bureau of Fisheries, vol. 24, p. 38, plate 4, fig. 5 (figure labeled "Turritopsis mutricula," on p. 37).

Turritopsis nutricula (in part), NutTing, 1901, Bull. U. S. Fish Commission for 1899, vol. 19, P. $375 \cdot$

Porocoryne carnea, Hargitr, 1901, American Naturalist, vol. $35, \mathrm{p} .582$, fig. 44 .

Podocoryne, Hazfn, igoz, Amer. Naturalist, vol. 36, p. 193 (regeneration).

\section{AMERICAN VARIETY.}

Adult medusa. - The bell is ellipsoidal in form and is about $3.5 \mathrm{~mm}$. in height. Gelatinous substance not very thick, but quite tough and rigid. There are about 24 to $32 \mathrm{mar}$ ginal tentacles which are about as long as the bell-height. The tentacles are not very flexible and are usually carried curled upward. The tentacle-bulbs are well developed and are filled with entodermal pigment granules. The velum is well developed. There are 4 straight and narrow radial-canals. The manubrium is flask-shaped and there is no peduncle. The mouth-opening is surrounded by 4 short, radially situated, unbranched, oral tentacles, each of which terminates in a knob-shaped cluster of nematocysts. The ripe ova and spermatozoa are found in the 4 interradii within the ectoderm of the manubrium. According to Ishikawa and Bunting, the ova originate in the entoderm, but the sperm originates and remains in the ectoderm. When the medusa is mature both ova and sperm are found in the ectoderm of the stomach. In the female, the ova are large and prominent and are spherical in form. The entoderm of the manubrium and of the tentacle-bulbs is red, or brown to red, in color.

II ydroid and young medusa.-No specific difference exists between the American and European hydroid stocks of Podocoryne. The hydroid (plate I4, fig. 2) is commonly found upon shells which are tenanted by the hermit-crab (Pagurus) and also upon the carapace of Limulus. The polypites arise at somewhat irregular intervals from a hydrorhiza which clings to the surface of the shell, etc., upon which the stock is growing. In young colonies the hy.drorhiza consists of an open network of anastomosing fibers, which are covered by a thin, delicate perisarc, and externally by a fleshy hydrocaulus, or coenosarc. As the colony becomes older, however, the fibers of the hydrorhiza form a closer network, and the chitinous perisarc fills in 
the spaces between them. Numerous short, chitinous spines are developed upon the crust which covers the fibers, and thus we find the polypites arising from a Hat, spinous base which adheres to the surface on which the colony is growing. The colony is composed of two kinds of hydrantlıs: sterile feeding-polypites, and reproductive gonostyles. The sterile feedingpolypites are spindle-shaped, being about twice as wide near the oral circlet of tentacles as they are at the base. They have 2 to 6 straight, stiff tentacles. The mouth is situated at the apex of a dome-shaped proboscis. They are very contractile and may vary in length from about 5 to $15 \mathrm{~mm}$. The reproductive polypites, or gonostyles, are frequently exactly similar in size and shape to the feeding-polypites, and, in fact, are probably merely feeding-polypites which

\begin{tabular}{|c|c|c|}
\hline & $\begin{array}{l}\text { Podocoryne carnea } \\
\text { Sars, of Europe. }\end{array}$ & $\begin{array}{c}\text { Podocoryne carnea } \\
\text { var.americana. }\end{array}$ \\
\hline $\begin{array}{l}\text { Number of tentacles when hiberated } \\
\text { from hydroid. }\end{array}$ & 4 & 4 to 8 . Usually 8. \\
\hline $\begin{array}{l}\text { Number of tentacles possessed by } \\
\text { mature medusa. }\end{array}$ & $\begin{array}{l}\text { Usually }+ \text { to } 8, \text { rarely } \\
\text { I } 6 \text { (Graeffe). }\end{array}$ & $\begin{array}{l}16 \text { to } 32 \text {. I'sually } \\
\text { about } 24 \text {. }\end{array}$ \\
\hline $\begin{array}{l}\text { Medusa-buds on interradial sides of } \\
\text { stomach of medusa. }\end{array}$ & $\begin{array}{l}\text { Observed by Sars, } \\
18_{4} 6 .\end{array}$ & $\begin{array}{l}\text { No medusa-buds } \\
\text { observed. }\end{array}$ \\
\hline
\end{tabular}
have developed medusa-buds (see plate I 4 , fig. $2, g$ ). In other instances the gonostyles are smaller and more slender, and possess not more than 4 to 8 tentacles (see $g^{\prime}$, fig. 2 ). The medusa-louds arise from a zone which is slightly below the circlet of oral tentacles. From 4 to 8 of these buds are usually to be seen upon each gonostyle. According to Martha Bunting, I894, it appears that the medusa-bud arises as an outpushing of hoth entoderm and ectoderm of the gonostyle. As the bud progresses in its development, we find the ova in the entoderm of the manubrium. When a later stage has been reached they migrate from the entodem into the ectoderm. The spermatozoa, on the other hand, originate in the ectoderm of the manubrium, as was shown by Weismann, I 883 . When set free the medusa usually has 8 tentacles: 4 radial and 4 interradial. The radial tentacles are usually better developed than the interradial and in some individuals there are but 4 tentacles at the time of liberation, the interradial ones not yet being developed.

It is remarkable that while in some stocks of Podocoryne the meduste are set free in an immature state, in others the medusa are mature when liberated, the manubrium being distended with sperm or ora, which are discharged almost immediately after the medusa is set free. It is possible, as Allman, I $87 \mathrm{I}$, suggests, that this difference may be due to the influence of local conditions, which may be favorable in the one case and not so in the other to an advanced development of the medusa. Krohn, I 85 I, and Loven, I 857 , have olserved stocks of the European form of Podocor yne which were setting free mature medusx. Indeed, we appear to have a parallel case in Sarsia on the Massachusetts coast, where immature medusa are liherated during the early spring months, whereas the medusa become ripe, discharge their genital products, and wither upon the hydroid stock in May. Good figures of Podocoryne stockswhich are setting free immature medusa have been given by Sars, 1846 ; Hincks, I 868 ; Allman, i 87 I ; etc. When set free the medusx commonly have 8 tentacles, 4 radial and 4 interradial. The radial tentacles are usually more advanced than the interradial, and in some few individuals there is no trace of interradial tentacles at the time when the medusa is liberated. The manubrium is short and fusiform and the mouth is surrounded by + radially situated, oral tentacles, each of which terminates in a knob-shaped cluster of nematocysts. When set free the medusa is about 0.5 to $0.6 \mathrm{~mm}$. in height.

In those medus $x$ which are set free in an immature condition there are at first 8 tentacles, but these increase in number as growth proceeds and finally, when the medusa is about $3.5 \mathrm{~mm}$. in height, there are usually about 32 tentacles, $8 \mathrm{in}$ each quadrant. The manubrium of the young, immature medusa is slender and fusiform, while in those medusa which are set free in a mature state it is globular and greatly distended with the genital products. The ectoderm of the hydroid is slightly bluish and translucent, while the entoderm is creamy-pink or silverywhite in color.

This species has been found upon the Atlantic coasts of Europe, in the Mediterranean Sea, and from Saldanha Bay, Cape Colony, South Africa. Levinsen, 1893 , records it from the 
west coast of Greenland, and we have found it in great abundance in Natragansett and Buzzard's Bays, on the southern coast of New England. It has not been taken at Beaufort, North Carolina, nor at any station farther south. The medusa are very common in Narragansett Bay from the middle of June until October, and I enjoyed exceptional opportunitics

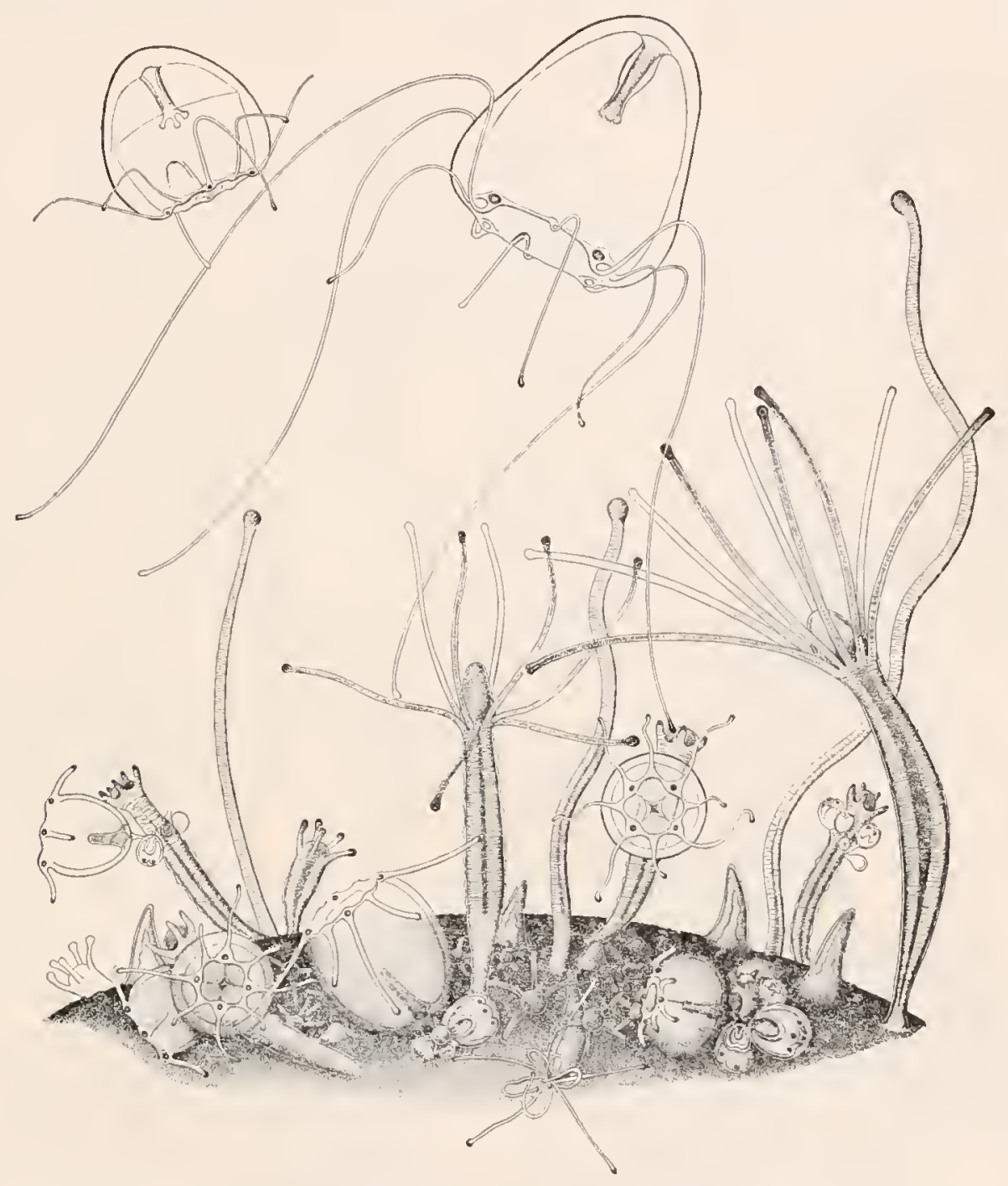

lira. 74.-Podocoryne camea, hydrosd and young medusa. Drawn from life by Professor William K. Brooks, and kindly presented to the author for publication in this work.

for observing their growth and development while studying at Dr. Alexander Agassiz's laboratory at Newport, in $1892-96$.

In 188 I- 82 de Vareme concluded that both eggs and sperm-cells originate in the entoderm of the cœenosarc of the hydroid and afterwards migrate into the medusa-bud. The more careful researches of Weismann, i $88_{3}$, however, refuted this view, showing that the male germ-cells originate in the ectoderm of the budding medusa, but do not wander from their place of origin. On the other hand, the female germ-cells may possibly originate in the ectoderm; if so they soon wander into the entoderm of the budding gonophore, then into the spadix of the medusa-bud and finally into the ectoderm of the manubrium of the medusa. According to the later studies of Ishikawa and of Bunting, however, the egg-cells originate in the entoderm of the medusa-bud and afterwards migrate into the ectoderm. 


\section{Genus TURRITOPSIS McCrady, I856.}

Turritopsis nutricula McCrady.

Oceania (Turritopsis) nutricula, Míc.Cradr, I 856 , Proc. Elliott Soc. Clarleston. pp. I-76, plate 4, fiss. I-Io.

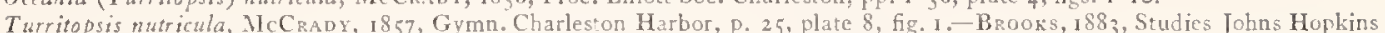

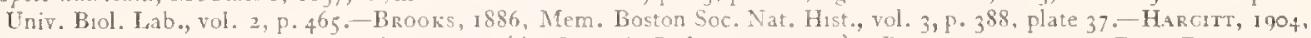
Bull. U. S. Bureau of Fisheries, vol. 24, p. 37 (the figure is Podocoryne carnea).-Rirtenhouse, 19o7, Proc. Boston Soc.

Nat. Hist., vol. 33, P. 437, plates 30-35, figs, 1-55 (derelopment).

Modería multitentacula. FEwkES, I881, Bull. Mus. Comp. Zool. at Harvarł College, vol. S, p. 149, plate 3, figs. 7-9.

Modeerin nutricula, EEvkes, I 882, Bull. Mus. Comp. Zool., vol. 9, p. 295.

non Turritopsis nutricula, Acsassiz, A., 1865, North Amer. Acal., P. 167, figs. 260, 270

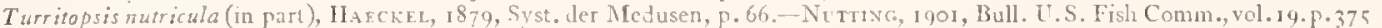
EukOPFAN MrDisa.

Oceania polycirrha, Keferstein, IS62, Zelt. fï wissen. Zuol., Bu. 12, p. 26, taf. 2, fign. 11-13.

Turritopsis polynema, HAECKEL, IS-9, Syst. der Medusen, p. 66.

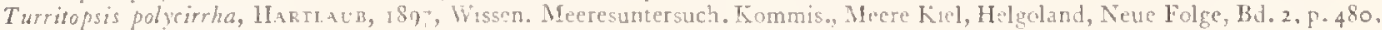
taf. $16 c$, fig. 2 .

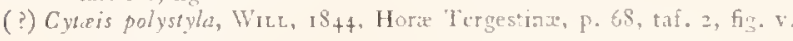

American medusa (plate $1+$ fig. IO). - Bell usually slightly pyriform and about + to 5 m. in height. Bell-walls unifomly thin. There are to to to simple marginal tentacles, which are all of about the same length and are somewhat shorter than the bell-heiglit. These tentacles are capable of much contraction or extension. Their hasal bulbs are large and there is a single. ectodermal pigment-sput upon the lower (centripetal) side of each tentacle near its place of origin from the basal luulb. The sufface of the tentacles is covered thickly with nematocystcells. The velum is well dcveloped. There are 4 straiglit, narrow radial-canals and a narrow circular vessel. The manulium is large and fills about half of the hell-cavity. The upper part of the manuhrium near the hase consists of 4 radially situated masses of large. highly vacuolated, entodermal cells, though the midst of which the + rabial-canals extend downward into the stomach. These cells are inteed only the entodermal walls of the radial-canals (plate I +, fig. I 3). The stomach is large and quadratic in cross-section. The cruciforn mouth is situated at the cxtremity of a short neck and is surounded by a row of nematocyst-bearing knohs (plate I5, fig. I 2). The gonads are developed upon the sides of the stomach. where they occur in the form of a double, longitudinal, swollen egion in cach adradius. Their outer surfaces are smouth. The entoderm of the stomach is dull-yellow or orange, or dullyellow streaked with orange. The tentacle-bulbs sometimes contain a litte entodermal orange pigment. The ocelli upen the tentacles are dark-hrown or orange.

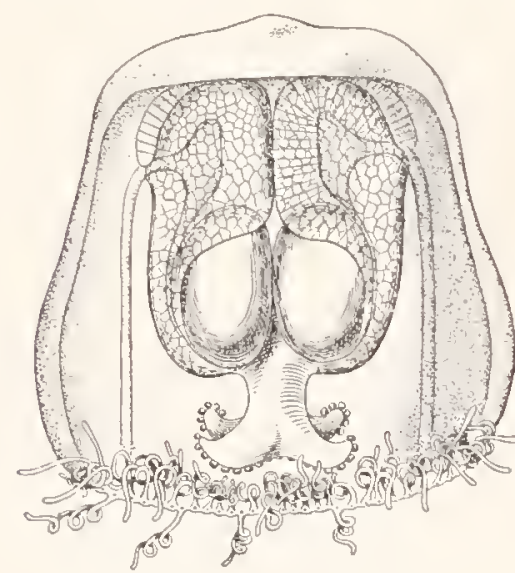

Fig. 75.--Turritopsis nuricula, after Brooks, in Mem. Boston Soc. Natural History.

Hydroid and young medusa.-The hydroid (fig. - 6 ) was found by Brooks, $188_{3}$, on piles of a wharf at Morehead City, North Carolina. It is a Dendroclor'a and closely related to D. dohmii Meismann. The stems of the hydroid are from 8 to $10 \mathrm{~mm}$. in height and bear large, terminal hrdranths. There are also numbers of short, side hranches which terminate in hydranths. The main stem and the side branches are incased in a loose, cylindrical perisare, which is thick and becomes incrusted with foreign matter. The perisare is not annulated, and terminates abruptly hy a sharp collar immediately below cach hydranth. The hydranth or feeding-polypite is long and fusiform and bears from is to 20 short, thick, filiform tertacles, which are arranged in three or more indefinite rows or wholls. The medusa-buds originate upon the sides of the stem at the bases of the hydranths. Each medusa-bud is borne upon a short stalk or peduncle and is closely invested by a thin capsule of perisarc. When set free the young medusa has $S$ tentacles. The manubrium is cone-shaped and there is a large peduncle formed of highly-vacuolated cells. + prominent, nematocyst bearing knohs surround the mouth. The hydranths are pale vellowish-red.

This medusa is found from the coast of Cuba to the southern coast of New England. being about equally ahundant in the northern and southern limits of its range. It is very common in the Bahamas and at Tortugas, Florida. In Charleston Harbor, South Carolina, 
it is commonly infested by larra of Cunoctantha octonaria McCrady, although it appears to be quite immune from this parasite in other places. I can detect no specific distinctions hetween this medusa and "Turritopsis polycir ha," which is occasionally seen off the Atlantic coast of France and Germany. This form is well figured by Keferstem, I862, and Hartlaub, I 897 , who are the only European students who have observed the medusa on the eastern side of the Atlantic.

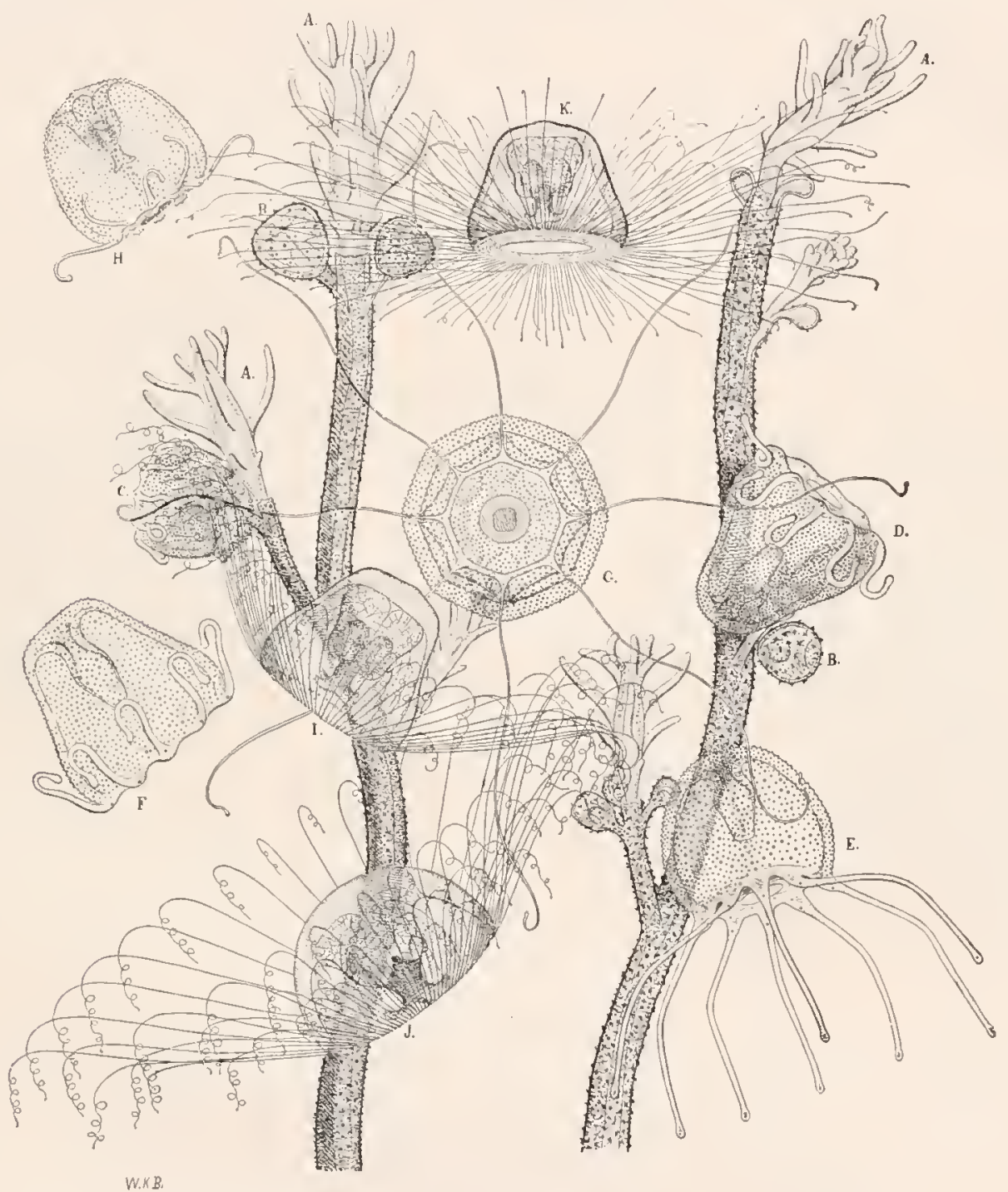

Fig. 76. - Turrioopsis nutricula, after Prooks, in Mem. Boston Soc. Nat. Hist. Hydroid and young medusa.

Rittenhouse, 1907, has made an elaborate study of the development of $\mathcal{T}$. nutricula. The ova develop in the ectoderm of the + interradial sides of the manubrium. The primitive ova grow by the absorption of ovarian cells around them, as is common in other hydromedusæ. The yolk-spheres in the ovum are formed from the ovarian cells which it absorbs. About 20 to 35 , rarely 50 or more, eggs are discharged into the water by the muscular rupture of the ovarian walls between 5 and 6 o'clock in the morning. The discharged eggs are spherical, o.I I 6 $\mathrm{mm}$. in diameter and have no membrane. They are yellowish-white, heavier than sea-water, and opaque. The outer layer of finely-granular ectoplasm is distinct from the coarsely granular, yolk-laden endoplasm. Soon after being discharged the egg gives off two polar bodies and is fertilized. Segmentation is total and approximately equal. The first two segmentation planes are meridional and the third equatorial. The blastomeres remain quite far apart, 


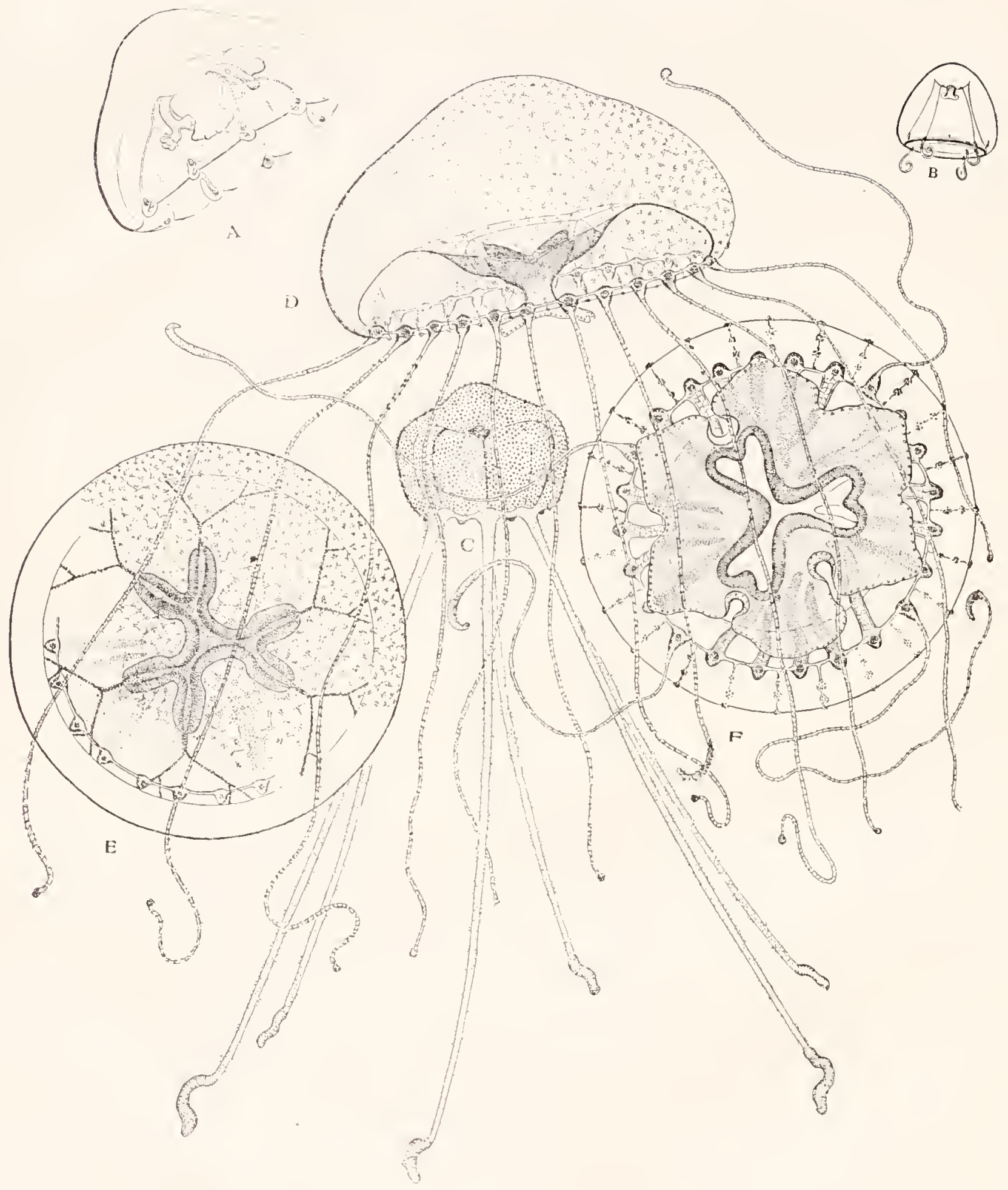

Fic, rola.- $A$ and $B$, Proboscidactla ormaic, var. gemmifera showing a young stage with stolons bearing nedusa buds. $C$ to $F$, young and mature stage of Willsia brooksia sp. nov ; having 6 primary radial-canals, 24 terminal ramouli. From Beaufort, North Carolina. Drawn from life, by Professor Brooks. 
touching only slightly. After this the cleavage becomes remarkably irregular, recalling the extraordinary condition observed by Hargitt in Pennaria. A solid morula is formed, which has no central segmentation cavity and which resembles a loosely-connected mass of irregularly grouped cells rather than an embryo of any metazoan. The cleavages follow one after another at intervals of 20 to 30 minutes.

As in Metschnikoff's Oceania armata and Hargitt's embryos of Pennaria, this irregularly shaped morula gradually changes into an oval embryo, the surface of which becomes ciliated, so that it swims upward from the bottom. This takes place at about 4 in the afternoon in eggs which were laid between 5 and 6 in the morning.

Rittenhouse finds that during this period, when the loose, irregularly shaped mass of cells shapes itself into an oval embryo, the ectoderm and entoderm are formed. During this period "the cell-boundaries are lost for a short time and a syncytium is formed. This syncytial structure is crowded with yolk-granules and nuclei are scattered throughout the protoplasm. The nuclei soon become more numerous near the periphery and the cell-walls begin to appear" between the peripheral nuclei. These peripheral cells are to become the ectoderm, which is soon separated from the inner, structureless mass by the development of the mesogloea. This inner mass afterwards acquires cell-boundaries between its nuclei, and still later a central cavity, the cœlenteric space, develops; and thus the entoderm is formed. This colenteric cavity does not develop, however, until the larva is 48 to 60 hours old. The syncytium condition in Turritopsis is much more complete than is seen according to Hargitt in Pennaria, or in Bougainvillia, according to Gerd, 1892 .

Rittenhouse finds that during the early stages of cell-division in Turritopsis the multiplication is solely by mitosis, but that later, when the embryo becomes a mere irregularly arranged mass of loosely-compacted cells, some of the nuclei divide amitotically.

When about 50 hours old the elongate, oval larva ceases to swim through the water and settles down upon its side on the bottom. The larva then becomes the hydrorhiza, or root, of the hydroid, and the first hydranth arises as a bud from about the middle of its length. The tentacles of the hydranth develop in indefinite whorls, with 4 tentacles in each whorl, the oldest tentacle being nearest to the mouth. In the mature hydroid the tentacles appear to be irregularly scattered rather than being arranged in whorls.

Turritopsis should be reared under more natural conditions than those of the ordinary laboratory in order to determine whether the remarkable, irregularly formed embryos described by Rittenlouse be normal or merely the result of pathological states induced by adverse conditions; but Miss Beckwith has recently shown that the cleavage of Pennaria is normally irregular as is described by Hargitt.

Rittenhouse finds that when the embryo is in the loose-celled, morula stage it may be divided into two masses, each one of which produces a normal planula larva of small size.

\section{Genus WILLSIA Forbes, 1846 .}

Willsia brooksii sp. nov.

Beautiful drawings of a young stage and also of the adult condision of this medusa were made by the late Prof. William K. Brooks, while he was at Beaufort, Nonls Carolina, and were found among his unpublished figures, after his death. They were kindly presented to me by the Department of Biology of Johns Hopkins University for publication in this work, and it seems but fitting that the species should be named in honor of the great naturalist who discovered it. It is closely allied and possibly identical with the European Willsia stellata, although the 3-rayed center of the stomach appears to distinguish it.

In the young stage there are 6 simple, slender radial-canals, $60^{\circ}$ apart. The bell-walls are relatively thin and the bell somewhat higher than a hemisphere with a bluntly pointed apex. The 6 tentacles are 5 to 6 times as long as the bell-diameter and have swollen, nematocyst-bearing, outer extremities.

In the mature medusa the bell is flatter than a hemisphere, thick walled, with a shallow bell-cavity. Twenty-four tentacles alternate with 24 exumbrella, nematocyst tracts each with several clusters of nettling cells. The manubrium has 6 lips. Stomach 3-rayed at center, but each ray forks, giving 6 ramuli, 6 primary radial-canals which bifurcate twice, giving 24 terminal branches. Gonads extend along sides of stomach. The size and color can not be determined from Professor Brooks's drawings. Found at Beaufort, N. C.

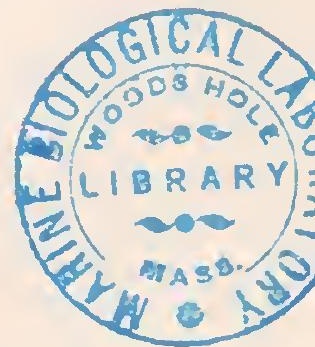


Genus EUCHEJLOTA McCrady, I857.

Eucheilota duodecimalis var. parvum.

Dipleuron parvum, Brooks, 1882, Studies Johns Hopkins Univ. Biol, Lab., vol, 2, p. 139.

This variety resembles $E$. duodecimalis in all respects excepting that the gonads are developed upon only 2 of the radial-canals. The gronads are spherical in shape and found upon 2 diametrically opposite radial-canals, near the circular ressel.

This form was found by Brooks at Beaufort, North Carolina, from June until August, and in 1904 I found it in a surface-tow taken early in December, off Cape Fear, North Carolina. It appears to be a local race or variety of $E$. duodecimalis.

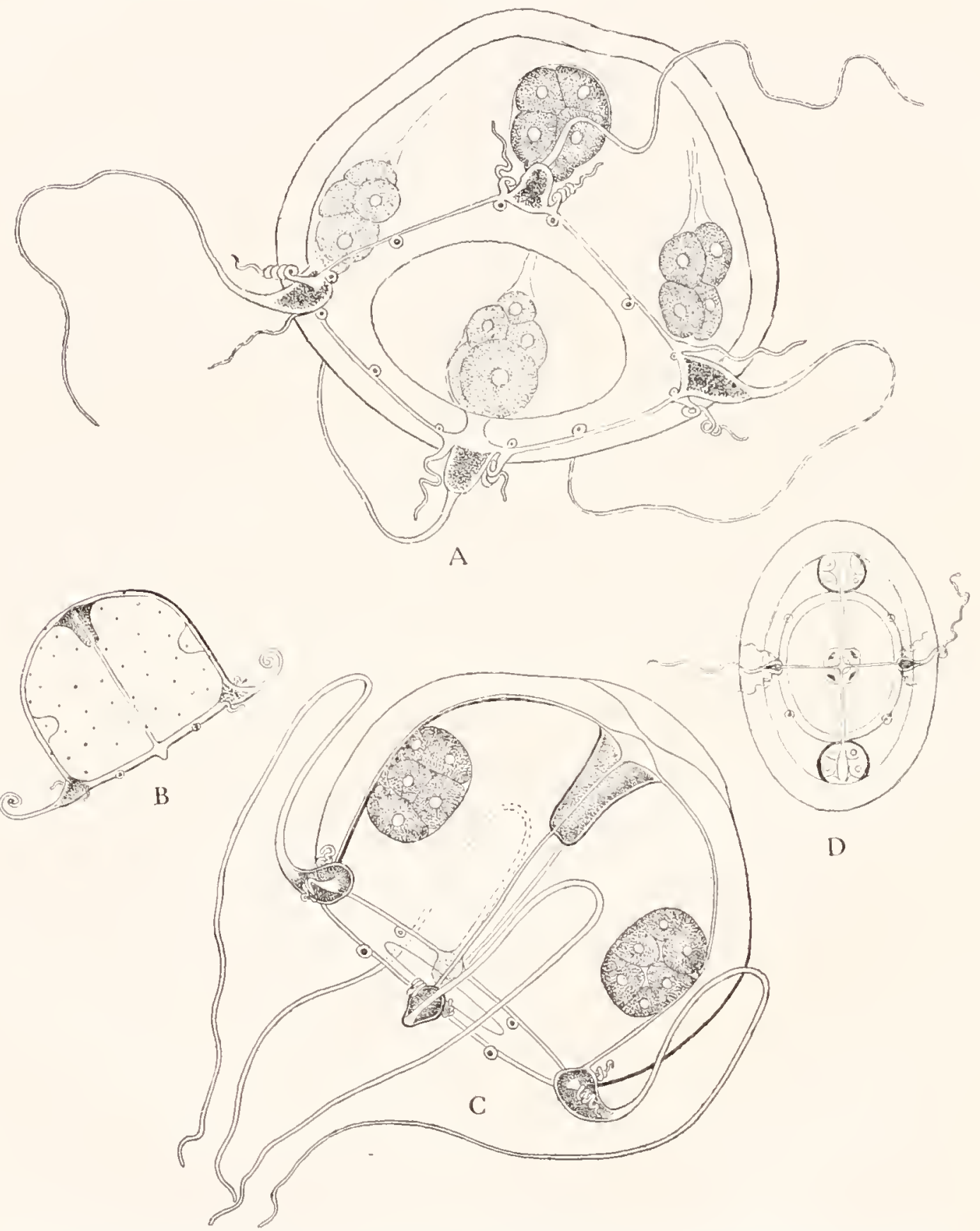

F16. 151a.-A, Eucheilota duodecimalis; B, С and D, Eucheilotaduodecimalis var, parvum. Drawn by the late Prof. William K. Brooks at Beaufort, North Carolina, and presented by the Department of Biology of Johns Hopkins University for publication in this work. 
Genus DIPLEUROSOMA Axel Boeck, 1866, sens, emend.

Dipleurosoma brooksii sp. nov.

This form is described from drawings made by the late Prof. William $\mathrm{K}$. Brooks, and found after his death among his unpublished figures. The drawings were generously presented to the author by the Department of Biology of the Johns Hopkins University for reproduction in this work.

Bell flatter than a hemisphere, evenly rounded, thin walled. Manubrium small, short, and 8 -sided. 8 simple lips, 4 long and 4 short. 8 radial-canals arise from the stomach; the 4 in the radii of the long lips are trident-shaped, each giving rise to 2 side branches. The 4 canals in the radii of the short lips are simple. Thus 16 terminal branches reach the circular vessel. In the specimen figured by Professor Brooks only 14 canals joined with
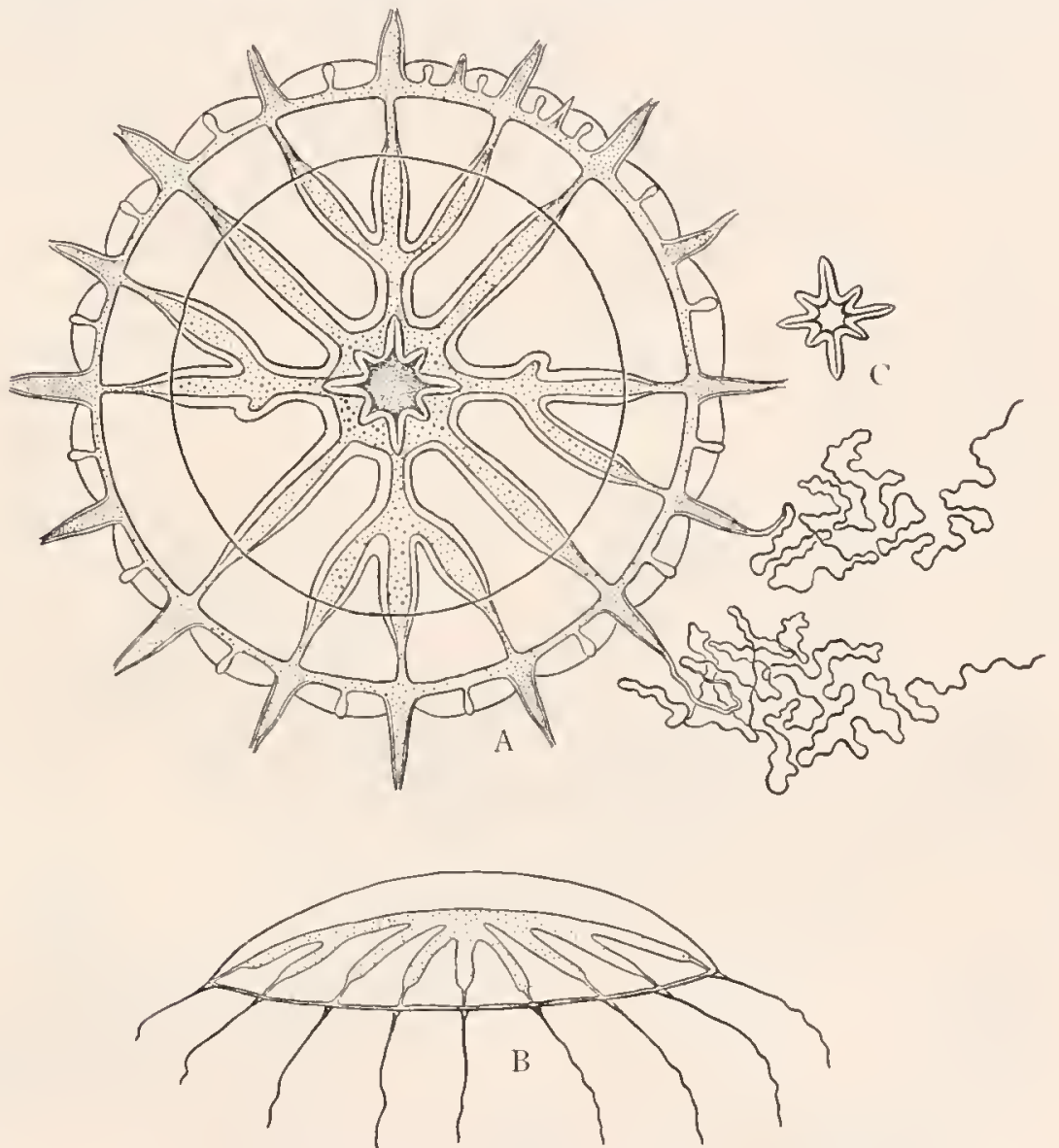

Fig. $118 \mathrm{a} .-$ Dipleurosoma brooksii sp. nov. A, oral view; B, side view with tentacles cut off short; c, oral view of lips.

Drawn from life by Professor Brooks.

the circular vessel, for two of the side branches of the main radial-canals failed to develop. There appear to be typically 16 tentacles, one at the base of each terminal branch of the radial-canals, although in two intervals there aresmall additional tentacles thus giving i 8 tentacles in the specimen figured by Professor Brooks. The tentacles have long, conical, tapering basal bulbs, which are hollow and very long, lash-like shafts, longer than the bell-diameter and very flexible. No ocelli are figured by Professor Brooks. The gonads are upon the sides of the 16 radial-canals, not touching the ring-canal but extending from the sides of the stomach outward. The velum is a wide, annular diaphragm. The size and color of the medusa can not be determined from Professor Brooks's drawings. The medusa was found at Nassau. Bahama Islands. 
Were it not for the absence of ocelli I would be inclined to regard this medusa as a hypertrophic specimen of Staurodiscus tetrastaurus in which the side branches of the 4 primary radial-canals had reached the circular vessel and 4 intermediate canals had developed. I have, however, never observed such a condition among many hundreds of apparently mature medusa of $S$. tetrastaurus found at Tortugas, Florida; and it seems probable therefore that Professor Brooks's medusa is a new species which may have been derived from a Staurodiscus-like ancestor.

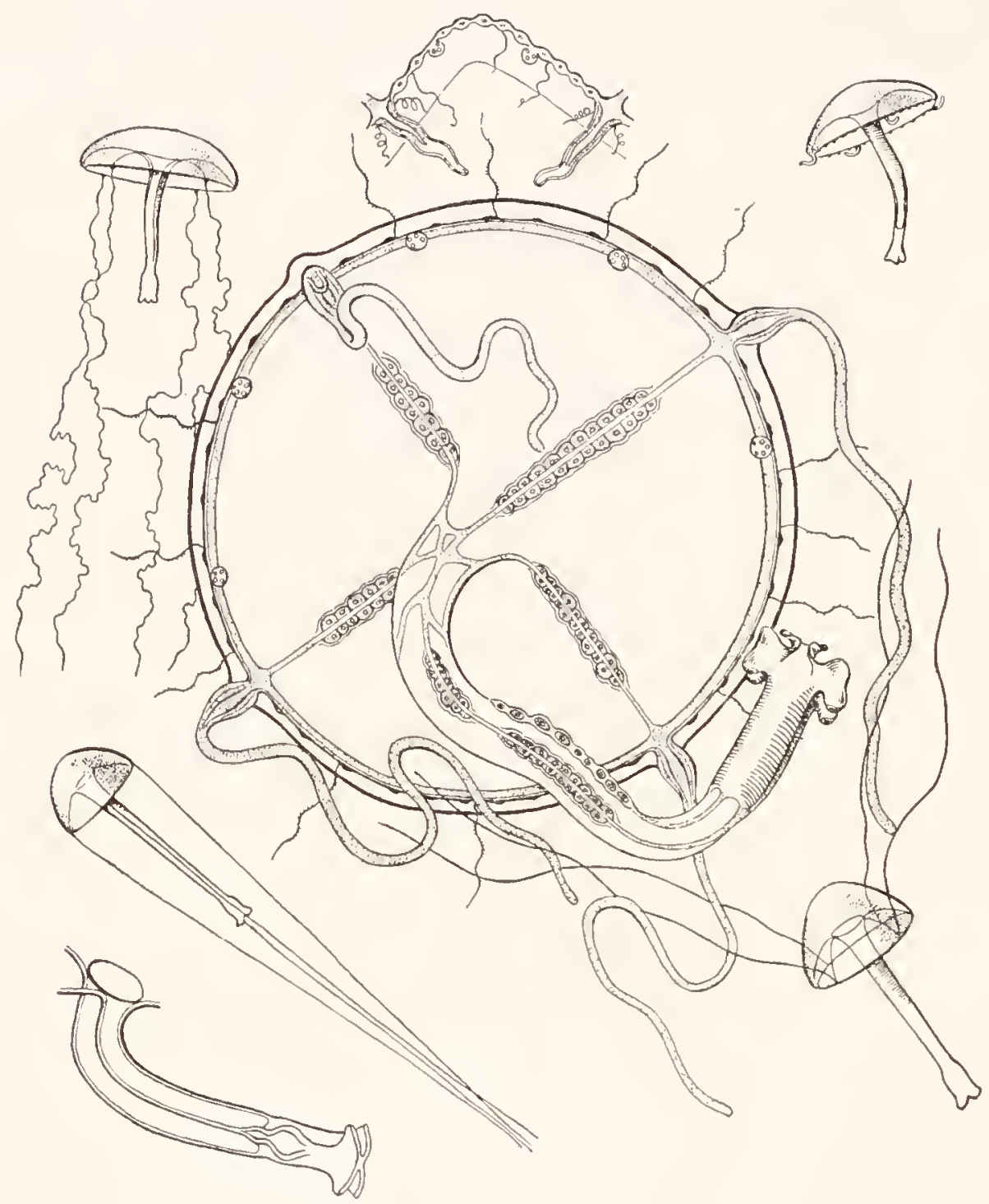

Fig. 160.-Euima mira, after Brooks, in Mem. Boston Soc. Nat. Hist., 1886. Small figures are of natural size and illustrate attitudes of the medusa. 
Genus EUTIMA McCrady, 1857.

Eutima mira McCrady.

Eutima mira, McCrapy, 1857, Gymn. Charleston Harbor, p. 88, plate 11, figs. 8, 9.-Agassiz, L., 186z, Cont. Nat. Hist. U. S., vol. 4, p. 363.-Agassiz, A., i865, North Amer. Acalephae, p. $116 .-$ Haeckel, 1879, Syst. der Medusen, p. $191 .-$ Brooks, I\$S 4 , Zool. Anzeiger, Jalirg. 7, p. 709; I 886, Mcm. Boston Soc. Nat. Hist., vol. 3, p. 395, plates 38,39 (hydroid).-Nutring, I9o1, Bull. U. S. Fish Commission, vol. 19, p. 378, fig. 93

Eutima limpida, Agassiz, A., 1865, North American Acal., p. II6, figs. 173 , 178.

Eutima emarginata (young medus3), Brooks, I 882, Studies Johns Hopkins Bial. Lab., vol. 2, p. IfI.

Eutima mira = E. limpida, HARGitT, I908, Biol. Bulletin, vol. I4, p. II I.

Eutima gracilis (young medusa), Fewres, 1881, Bull. Museum Comp. Zool. at Harvard College, vol.8, p. 158, plate 5, figs. I-4.

Bell about 1.5 times as broad as high, about 15 to $30 \mathrm{~mm}$. in diameter. There are 4 radially situated tentacles, each about 3 times as long as bell-diameter; also about 100 small, rudimentary nodules upon the bell-margin, some of which give rise to cirri. There are usually no lateral cirri flanking the tentacles when adult, but these commonly occur in the young medusa. There are 8 lithocysts, 2 in each quadrant. Each lithocyst contains 4 to 8 spherical, highly refractive concretions. Velum quite well developed. There are 4 straight, slender radial-

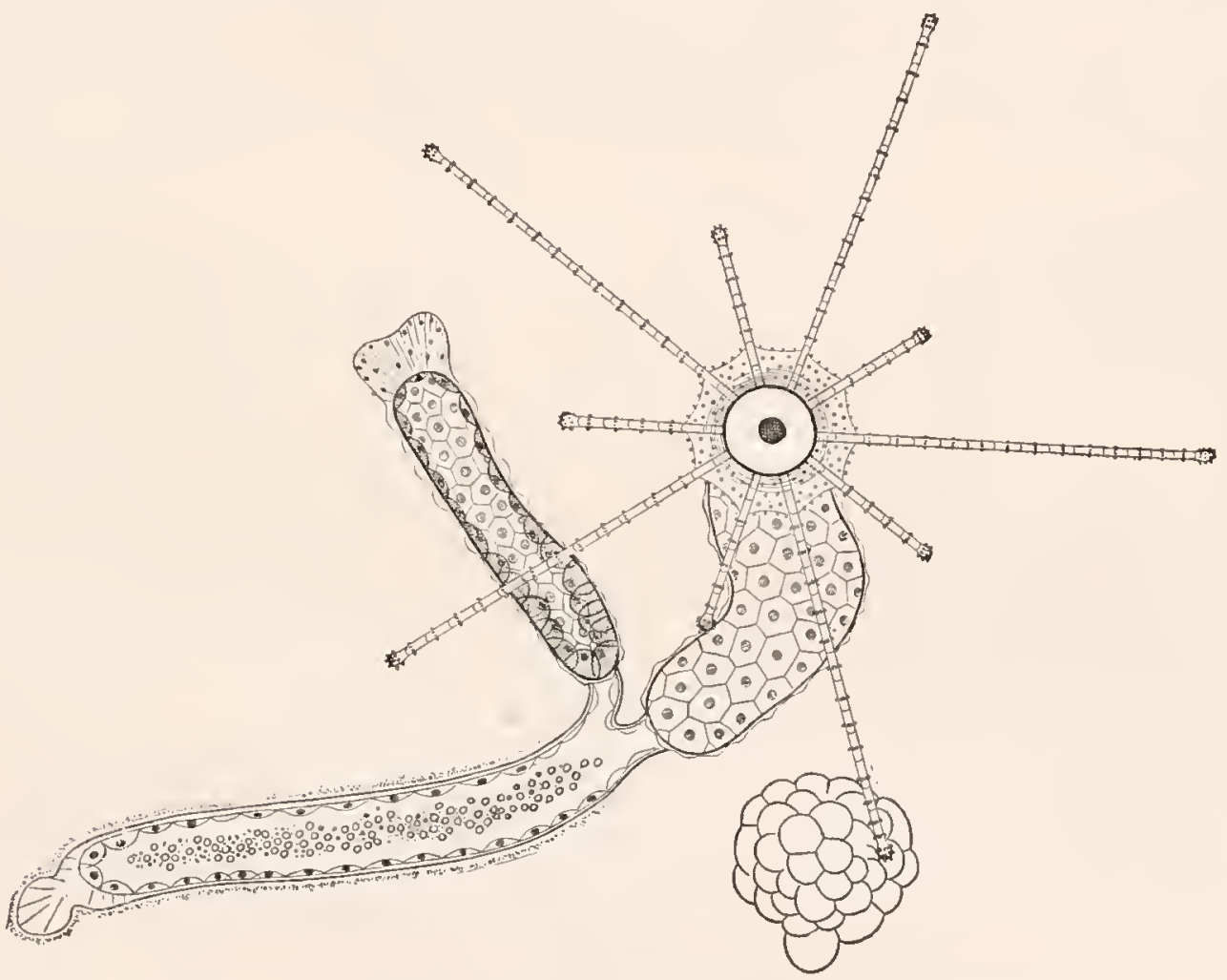

F1G. I61.-Larva of Eutima mira, after Brooks, in Mem. Boston Soc. Nat. Hist., vol. 3.

canals and a narrow circular vessel. The peduncle is about 3 times as long as height of bell, long, conical, and tapering gradually throughout its length from inner apex of bell-cavity to stomach. Stomach small and flask-shaped, its proximal part, near point of union with peduncle, thrown into complex folds. There are 4 simple, slightly recurved lips. The gonads are situated upon the radial tubes, in two separate regions, one upon the peduncle, and one upon the subumbrella.

The stomach, gonads, and tentacles, opaque blue-white in color. Many specimens display green entodermal pigment in the stomach and in the basal bulbs of the $t$ long tentacles.

The medusa is common at the Tortugas, Florida; Charleston, South Carolina; and Beaufort, North Carolina. It is an occasional visitant to Newport, Rhode Island, and to 
Woods Hole, Massachusetts, late in summer, being abundant in some years and rare in others. I am in accord with Hargitt in believing that E. mira is identical with E. limpida.

The development of Eutima mira has been studied by Brooks, 1884 and 1886 , who reared the hydroid from the egg. The gastrula is formed by delamination of the entoderm from the inner ends of the ectoderm cells. This takes place most rapidly at the narrow end of the pear-shaped planula. This narrow end afterwards becomes invaginated; the invaginated cells are, however, ectodemal, and have nothing to do with the gastrula cavity, but they form the cement gland which soon serves to attach the Iarva. One lip of this orifice of invagination grows faster than the other, so that the cavity is soon pushed to one side and the larva becomes bilateral. When the larva attaches itself this invaginated ectoderm is protruded and pours out its cement. The planula then elongates and forms a layer of perisarc which fastens it throughout its entire length. It thus becomes a hydrorhiza, not a hydranth. The first hydranth buds out at right angles to the length of the hydrorhiza at the end opposite to the cement gland. As soon as the first hydranth has acquired mouth and tentacles another buds out close to the base of the first and so on. The planula, therefore, persists as a root (hydrorhiza) and produces the hydranths by budding.

The young hydranth has a tentacular basal web and 5 large alternating with 5 smaller tentacles; 10 in all. The body of the hydranth is elongated and cylindrical, and is not covered by the perisarc which invests the unannulated stem. The hydroid is a Campanopsis, very similar to that from which Claus, 1881 , reared Eutima (Octorchis) gegenbauri.

\section{Eutima cuculata Brooks.}

Eutima cuculata, Brooks, $188_{3}$, Studies Johns Hopkins Univ, Biol. Lab., vol. 2, p. 140.

Bell about $8 \mathrm{~mm}$. in diameter and quite flat, being about 4 times as wide as high. The gelatinous substance is quite thick in the center, so that the cavity of the bell is very shallow and forms less than half of the total height of the bell. The gelatinous substance diminishes gradually in thickness from the center of the margin, where it forms a thin edge. 4 slender tentacles, which are 3 or 4 times as long as bell-diameter. The basal bulbs of these tentacles are small and there are no lateral cirri. Above the base of each tentacle is a small semicircular Hap or hood, which is formed from the gelatinous substance of the bell. There are 9 or Io very small marginal cirri in each quadrant. There are 8 lithocysts, 2 in each quadrant. Each lithocyst contains 3 to $\&$ spherical concretions. There are + slender radial-tubes. The peduncle is about as long as the bell diameter. It is conical above and prismatic below. Stomach about one-fourth as long as peduncle, with 4 simple lips. There are 4 gonads upon the + radial-canals, one on each canal. They extend from near the hell-margin to base of peduncle, but do not run down along the prismatic part of the peduncle.

The stomach and the entoderm of the tentacle-bulbs are intense green by reflected light.

This species was found by Professor Brooks at Beaufort, North Carolina, on August 7. 1880 .

The bell is Hatter than in Entima mira McCrady, the tentacles are longer, and the marginal cirri less numerous, but the only really distinctive feature appears to be the semicircular flaps above each tentacle-bulb. 
Genus PERSA McCrady, I857.

Persa incolorata McCrady.

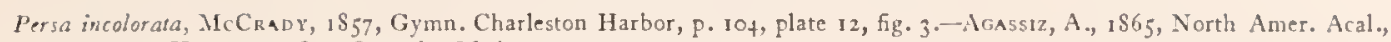
p. 50.-HAECKEL, 1879, Syst. der Medusen, p. 279 .

Bell oval and about $3 \mathrm{~mm}$. in height and $1.5 \mathrm{~mm}$. in diameter; walls thin. There are a large number of long, brittle, club-shaped, ciliated tentacles. 8 sensory-clubs between the 8 radial tubes. Velum large and muscular. 8 very narrow, straight radial tubes and a slender circular vessel. Peduncle short and conical. Stomach cylindrical, about half as long as bellheight, with + long cruciform lips. The 2 gonads a re developed on 2 diametrically opposed radial tubes. They arise from these tubes upon the subumbrella and project invard into the bell-cavity.

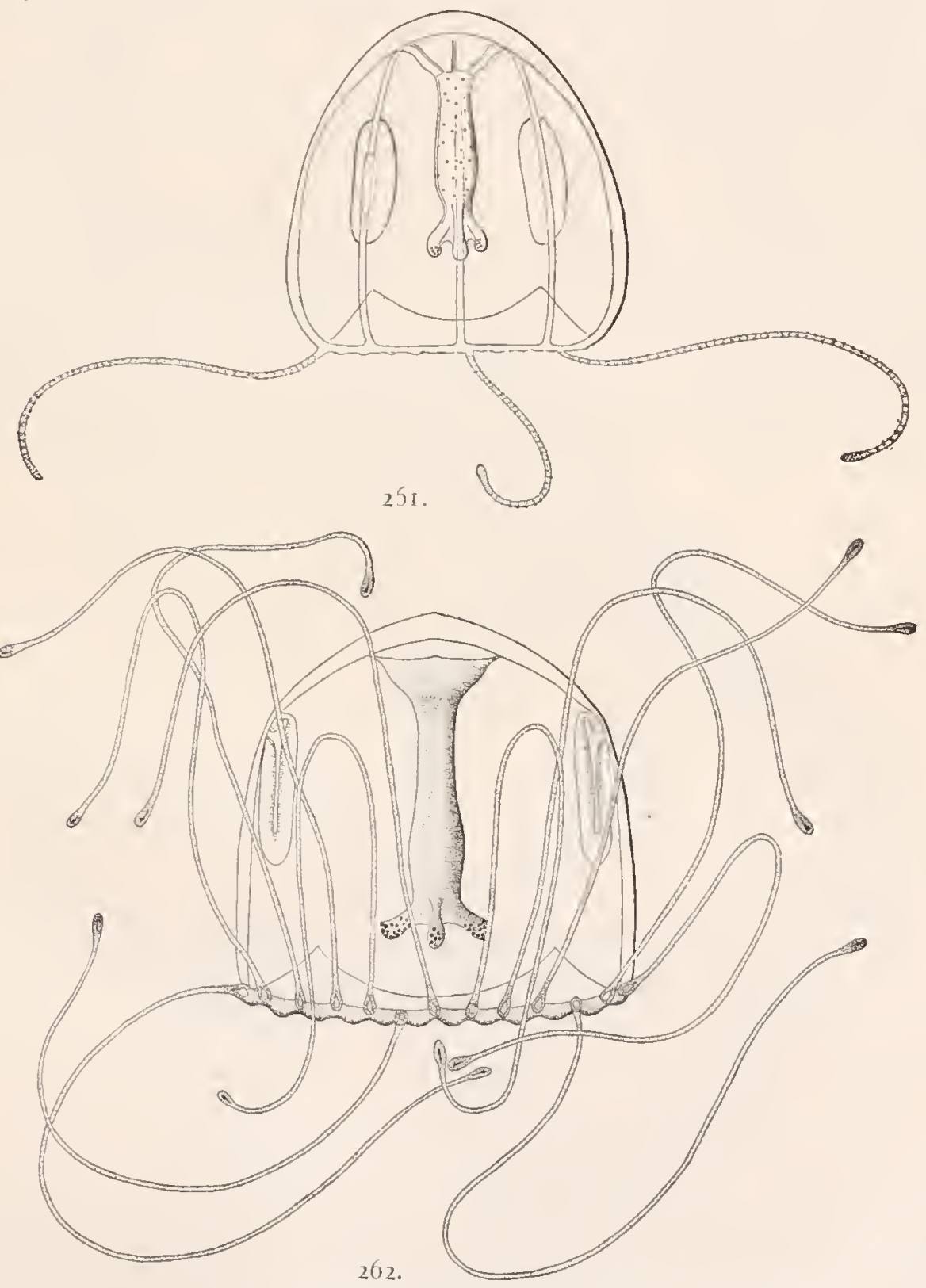

Fig. 261.-Persa incolorata, young medusa, from Beaufort, North Carolina. Fig. 262.-Persa incoloraia, mature medusa, from Beaufort, North Carolina. Drawn from life, by Prof. W. K. Brooks.

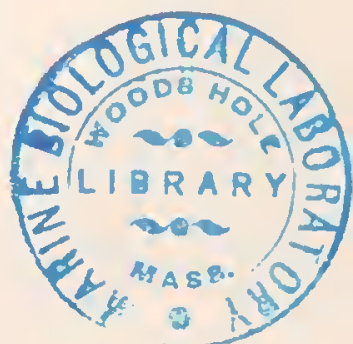


The animal is transparent, excepting for the gonads, which are pale-yellow.

This rare species was found by McCrady in 1857 in Charleston Harbor, South Carolina, and Brooks has found it in abundance during the summer at Beaufort, North Carolina. I believe it to be identical with the Mediterranean Persa.

The figures of the medusa here presented were drawn from nature by the late Professor William K. Brooks, who kindly presented them to me for use in this work.

Genus CUNOCTANTHA Haeckel, 1879 , sens emend.

Cunoctantha octonaria Haeckel.

Cunina octonaria, Mr Crady, 1857, Gymn. Charleston Harbor, p. 109, plate 12, figs. 4, 5; Proc. Elliott Soc. Nat. Hist. Charleston, S. C., vol. 1, plates 4-7.-AGassiz, L., 1862, Cont. Nat. Hist. U. S., vol. 4, p. 168.-Brooks, $188_{3}$, Studies Biol. Lab. Johns Hopkins Univ., vol. 2, p. 467; 1884 , Zool. Anzeiger, Jahrg. 7, p. 710; 1886 , Johns Hopkins Univ. Circular, No. 49, P. 86.-MaAs, 1893, Hrgeb. der Plankton Exped., Bd. 2, K. c., P. 53.-Agassiz, A., and Mayrk, 1899 , Bull. Mus. Comp. Zonl. at Harvard College, vol. 32 , p. 166 .

Foneolia octonaria, Acassiz, A., 1865 , North Amer. Acal., p. 51 .

Cunocionulu octonaria, Hafckt, 1879 , Syst. der Medusen, p. 316.-Broors, 1\$86, Mem. Boston Soc. Nat. Hist., vol. 3, P. 361 , plates 43, 44. - II ILson, II. V., 1887, Studies Biol. Lab. Johns Hopkins Uriv., vol. 4, P. 95, plates I-3, I 9 figs.-Ma.4s, I892, Zoolog. Jahrb. Anat. Abth., B.1. 5, Heft 2, P. 274.-Bigelow, H. B., I go9, Mem. Mus. Comp. Zool. at Harvard College, vol. $37, \mathrm{P} .52$, plates 14,15 , and 17 .

Mature medusa (plate 55, fig. I).-Bell about $7 \mathrm{~mm}$. in diameter, flatter than a hemisphere. 8 tapering tentacles, somewhat longer than bell-radius, project from sides of bell about midway between margin and apex; these tentacles are stiff and capable of but little movement and are carried bent downward in scimitar-like curves. The entodermal core of each tentacle consists of a row of disk-shaped, vacuolated cells. This core projects inward into the gelatinous substance of the exumbrella, immediately above the middle of the outer edge of one of the $S$ radial stomach-pouches. The root of each tentacle, where it fits into the gelatinous substance of the exumbrella, is thus covered with two layers of ectoderm, one being

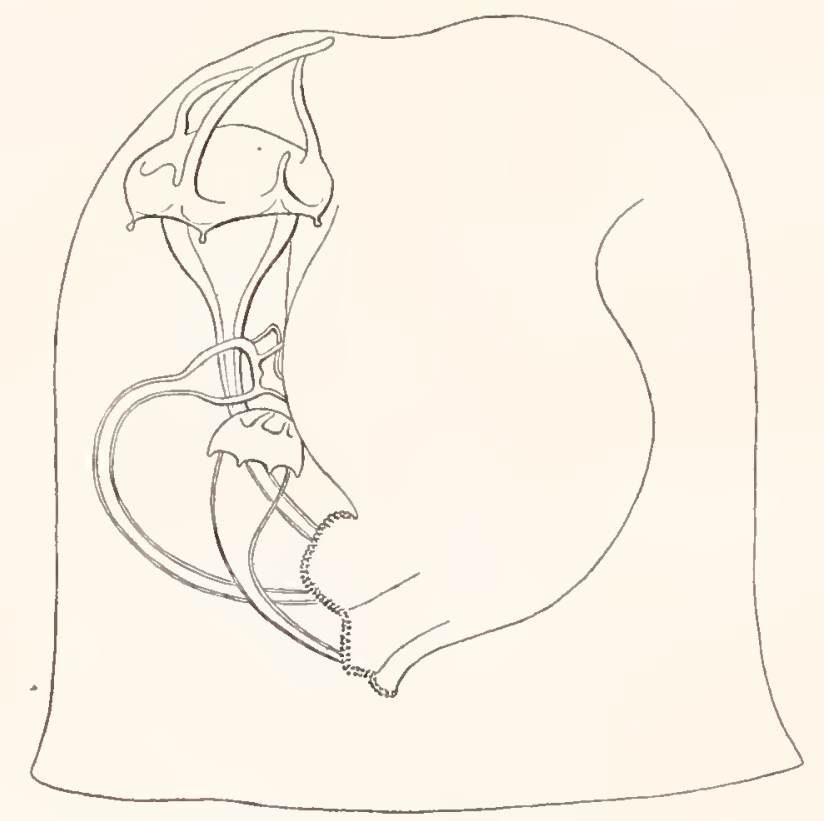

FIG. 305.-Larvse of Cunoctantha attached to mouth of Turrifopsis nutricula.

From drawing by Prof. W. K. Brooks.

continuous with the general ectoderm covering the exumbrella and the other is continuous with the ectoderm of the main shaft of the tentacle. The ectoderm of the shaft of each tentacle contains many nematocysts and also deep-lying muscle fibers. Just beneath and centrifugal to each tentacle-root is a thick pad of ectoderm-cells. This is the "peronium" of Haeckel and it probably serves to support the tentacle that arises immediately above it. 8 loops of 


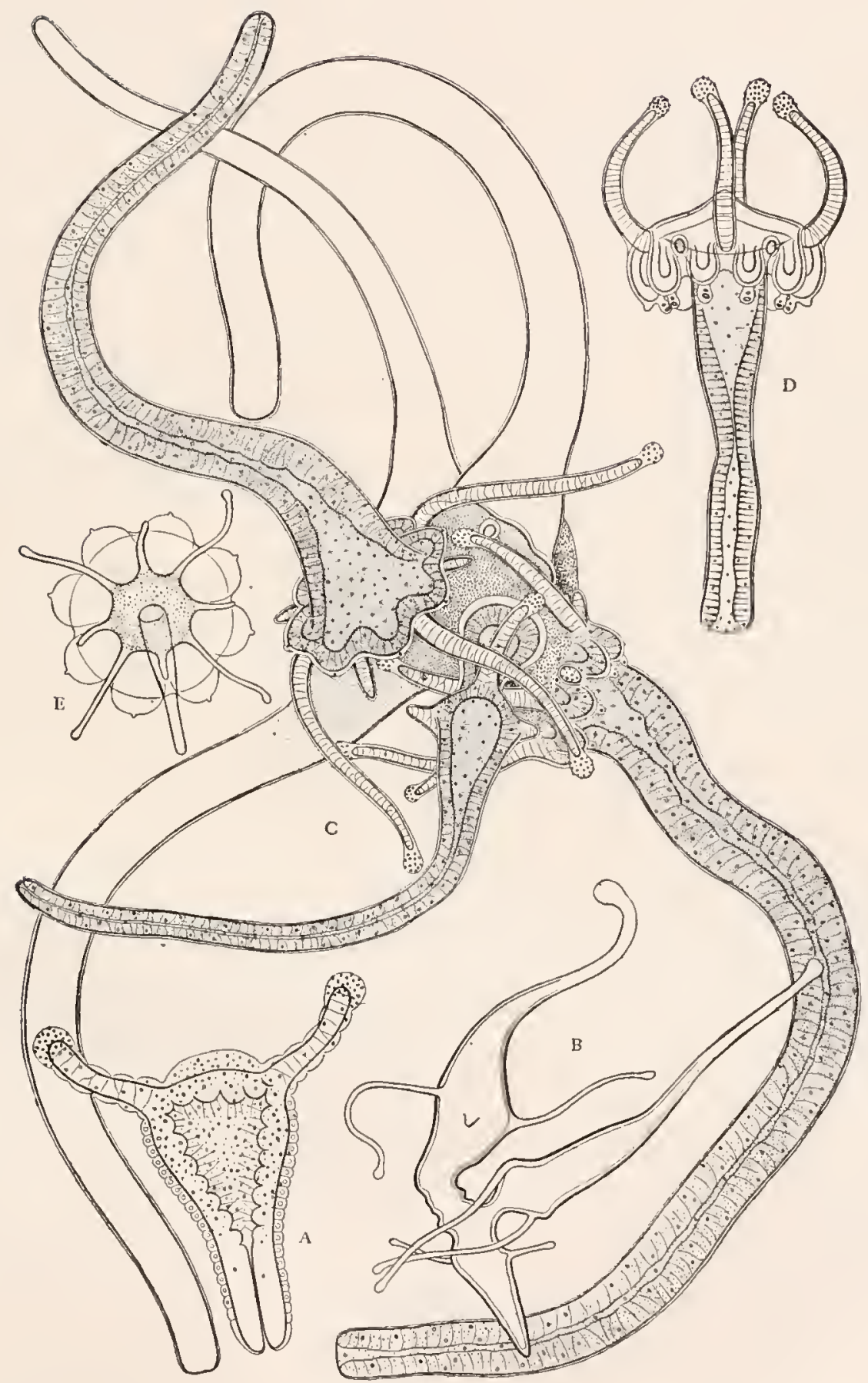

Fig. 30..-Cunoctartha octonaria, after Brooks, in Mem. Boston Soc. Nat. Hist., vol. 3. Showing development of actinula larva and young medusa.

$A$, young actinula. $B$ and $C$, budding actinulx giving rise to medusa-buds. $D$, young medusa with only + tentacles. $E$, aboral view of young medusa. 
the nerve-cord extend outward from the 8 peronia to the sense-organs upon the bell-margin. These 8 loops are put into connection one with another by means of nerve tracts that run through the peronia. Thus the nervous system consists of an 8-lobed, star-shaped ring of ciliated ectodermal cells situated upon the exumbrella (see plate 55, figs. I and 2, $n, n$ ).

In the adult medusa there are typically 24 marginal sense-organs, 3 in each octant of the bell, although occasionally there are as few as 2 or as many as 5 in an octant. Each sensory club is situated upon a small, hemispherical elevation of the bell-margin called the sensory cushion. The sensory cushion is formed from the cells of the nerve-cord, which at this place are elongate and spindle-shaped and bear long delicate bristles. Centripetal to the sensory cushion, on the exumbrella surface of the bell, there is a small, elliptical, elevated ridge, the otoporpa, composed of a single layer of cube-shaped ectoderm-cells and containing a number of nematocys:s (see plate 55, figs. I and 2,0). The sensory-club is rod-like and cylindrical and is attached to the sensory cushion by means of a short, narrow neck (see plate 55, fig. $\mathrm{I}^{\prime}$ ). Each sensory-club contains two concretions that are situated within the entodermal core of the club. The proximal otolith is small and spherical, while the distal is large, flat, and crystalline.

The velum is more complex than in most hydromedusa, for it consists not only of a simple annular membrane (see plate 55, figs. I and 2, v) that serves to partially close the opening of the bell-cavity; but in addition it extends upward as $8 \wedge$-shaped webs between the 8 loops of the nerve-cord (see plate 55, figs. 1 and $2 v^{\prime}$ ), and thus it is that, morphologically speaking, the margin of the exumbrella is bounded ly the nerve-cord and hence the true form of the disk is to be considered as an 8 -raved star, although the thin webs of the velum stretched between the rays give it the appearance of a hemispherical bell.

Manubrium cone-shaped and there are 4 perradial, cruciform lips. 8 gastric sacs radiate outward from the central siomach-cavity, each sac being found in a tentacular radius. There are no radial-canals and no ring-canals in this species. The gonads are developed in the ectoderm of the subumbrella immediately beneath the 8 gastric sacs.

The medusa is colorless with the exception of a delicate sage-green tinge of the enioderm near the lips and occasionally in the tentacles.

\section{Genus PELAGia Péron and Lesueur, r8o9}

Pelagia noctiluca Péron and Lesueur.

Medusa noctiluca, Forskal, 1775 , Descript anim. itin. orient., p. rog.

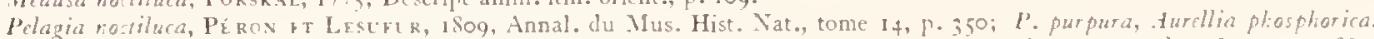

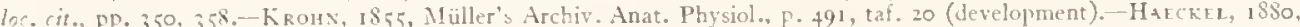
Spst.der Iedusen. 505 (list of authors and names).-Kowalfiskr, 1873 , Mem. Imp. Soc. Lovers of Nat. Hist.. Moscow, vol. 10. part 2. p. 7. plate ; (development). - Havisw, 1883. Zeit. für wissen. Zool.. Bd. 38, p. 422, taf. 32 (development and structure of gonads). Metschnikorf, i $\$ \$ 5$, Embryol. Studien an Medusen, Wien., F. 24 (ege); 67 (segrentatiun); 100 (larva); taf, 10, fign. 23-28.-Movaco, Prince of, 1887, Comp. Rend. Paris, tome 104, p. 452 (svarming habits of the medusa). - Vtyiörfen, 1888 . Bibliotheca Zoologica, Heft. 3, p. 8, taf. 1, fign. 5, 6; taf. 6, fign. 1-5; 19c8, Deutsch, Südpclar Expedition, 1901-1903, Bd. 10, Zool. 2, p. 38.-Goftre, 1893, Zeit. für wissen. Zool., Bd. 55, p. 59.11 fign., taf. 30-31; 1893, Sizungster. Aliad. Wissen. Berlin, p. 853 (development). Sch4xfi, iq10, Zool. Anzeiger, B 1. 35. F. 407 (histology of cögsnesis).

The following is a description of a typical, adult specimen from the Bay of Naples: Disk somewhat higler than a hemisphere when contracted, but flatter than a hemisphere when expanded. In ordinary contraction it is about 49 to $55 \mathrm{~mm}$. in diameier and $31 \mathrm{~mm}$. high. Sides of hell relatively straight and sloping. the apex flat. Numerous nettle-warts over the exumbrella, arranged in more or less irregular lines radiating from aboral apex of exumbrella. These warts are rich orange-red in color and are elongate and linear, sometimes with, but more often without, cross-foldings. Near the hell-margin, however, they lose their linear shape and become small, simple, and more or less oval.

The 8 marginal sense-organs are set in deep niches in the perradii and interradii. The sense-club has no ocellus, but contains only a terminal mass of deeply pigmented orange-colored crystalline concretions of entodernal origin. There is no sensory pit in the exumbrella above the sense-club. The 8 hollow, tapering tentacles are each about twice $(115 \mathrm{~mm}$.) as long as the bell-diameter. 
There are 16 subrectangular marginal lappets, with shallow median notches and rounded angles. The septun between the ultimate branches of the radiating stomach-pouches in the marginal lappets is twice as wide as the ulimate pouches themselves. The 4-sided throattube is as long as the bell-radius. The + lanceolate lips or palps, with their complexly folded margins are each about $\mathrm{I} .33$ as long as the bell-dianeter. Thus in an adult medusa with a disk $49 \mathrm{~mm}$. wide the palps were $68 \mathrm{~mm}$. long.

The bell has a rich rose-purple tinge; the gonads, the entodermal cores and the tentacles being especially deep in this color. The warts upon the exumbrella and along the outer edges of the palps are orange-brownish red.

This medusa is abundant at times in the Mediterranean, especially in summer, al hough large specimens are rarely seen in winter. It may be locally abundant during several successive seasons and then vanish for vears. For many years it was all but unknown in the Bay of Naples but since 1900 it has been one of the commonest Scyphomedusa in this region. It ranges widely over the warm regions of the Atlantic.

The development has been studied by Krohn, Kowalevsky, Hamann, Goetre, Hyde, and Metschnikoff. Hamann, I883, has made a detailed study of the development of the gonads, and their structure has been described by the brothers Hertwig, 1878 . They appear as 4 interradial, elongate ridges in the entoderm of the subumbrella. The entoderm forms a series of follicles in which the sex-cells develop and then migrate into a gelatinous lamella between the layers of entoderm.

According to Metschnikoff, the egr is violet-brown and is laid between 12 and 2 in the afternoon, in December, in the Mediterranean. Segmentation is total and nearly equal, and a very large central segmentation-cavity is formed. The gastrula results from invagination at the hinder end of the body. The blastopore does not close, but forms the mouth of the larva. Thus, according to Goette, 1893 , the mouth is ectodermal and forms by invagination at the hinder end of the larva, but the invaginated sac by no means fills the segmentation cavity. The first pair of stomach-pouches arise from the entoderm and are $180^{\circ}$ apart, then follows an ectodermal pair $90^{\circ}$ away from the first. The latter then develop 2 lateral pouches each, and at a later period the entodermal pair each gives rise to 2 lateral pouches, thus giving a larva with 6 eciodermal and 6 entodermal stomach-pouches; finally the ectodermal pouches give rise to 4 new adradial pouches and the larva has 16 stomach-pouches-1o ectodermal and 6 entodermal. There is thus a striking analogy between its development and that of the scyphostoma of Aurellia, according to Goette.

The external features of the transformation of the free-swimming larva into the medusa have been studied by Krohn (1855), Kowalevsky (1873), eic. The mouth-end of the larva become expanded and crater-like, with the mouth at summit of central cone of crater. The depressed region around the cone becomes the subumbrella. The lappets, into which the gastrovascular cavity is continued, grow out at intervals around the margin. The covering of cilia is lost from the body of the larva and it begins to swim by means of rhythmical contractions of its oral disk. Thus the free-swimming scyphostoma is converted into a medusa without s'robilization (see Goette, I893).

Reasoning by analogy from the excellent work of Hyde, I $89+$ (Zeit. fuir wissen. Zool., Bd. 58, p. 531), upon Aurellia, it is probable that only the subumbrella floor of the second pair of evaginated gastric pouches is formed from ectoderm, their exumbrella sides being of entoderm. (See also Hadzi's work upon Chrysaora.) 
Pelagia cyanella Péron and Lesueur.

Medusa pelagica, Linne, 1758, Systema Natura, Ed. 10, p. 660.

Medusa pelagica, Linné, 1766, Systema Natura, Ed.12, P. 1098.-1788 (Gmelin), tomus 1, pars 6, p. 3154. Pelagia cyanella, Péron et Lesueur, 1809 , Ann. Mus. Hist. Nat. Paris, tom. 14, p. 349, No. 66.

Diandeo cyanello, Lamarck, 1817 , Hist. Anim. sans vert., tome 2, p. 507

Pelagia cyanella, Eschscholtz, 1829, Syst. der Acalephen, P. 75, taf. 6, fig. 1.-Bosc, 1830, Hist. Nat. des Vers., Ed. 2, tome 2, p. 140, plate 17, fig. 3.-Agassiz, L., 1862, Cont. Nat. Hist. U. S., vol. 4, Pp. 128, 164; Ibid., 1860, vol. 3, plate 12, figs. 1-16.-Agassiz, A., 1865, North Amer. Acal., p. 47, fig. 68.--Hafcker, r880, Syst. der Mledusen, p. 507.-VANHörfrn, 1888, Bibliotheca Zoologica, Bd.1, Heft. 3, p. 22,-Bigelow, 189o, Johns Hopkins Univ. Circ., vol. 9, No. 80, p. 66.-HArgits, 1904, Bull. U. S. Bureau of Fisheries, vol. 24, p. 70, plate 7, fig. I.

This American medusa is very closely related to the European $P$. noctiluca, of which it is apparently only a local variety.

Bell about to $\mathrm{mm}$. high and $50 \mathrm{~mm}$. broad; somewhat fuller than a hemisphere, being a little less broad at margin than a short distance above. Numerous small wart-like nematocyst capsules are sprinkled thickly over the exumbrella and are especially thick in a zone at about mid-height of bell; these protuberances are reddish in color and tend to be arranged in radiating lines. 8 very long, highly contractile, hollow tentacles alternate with 8 marginal sense-organs. Each sense-club is set within a niche between two adjacent lappets and is protected on the outer side by a partial web between the lappets. The club is hollow and has no ocellus, but contains a terminal, entodermal mass of crystalline concretions which are deeply pigmented. 16 marginal lappets, hemispherical in shape. There is a long, narrow, 4 -sided proboscis, the radial corners of which extend downward as 4 long, flexible mouth-arms, the free edges of which are complexly crenulated. The proboscis, together with the mouth-arms, or palps, is about 3 times as long as bell-height. There are 4 complexly folded horse-shoeshaped gonads in interradial positions upon the floor of the subumbrella, and immediately centripetal to them are 4 subgenital pits or cavities extending inward from the outer surface of the subumbrella. The quadrangular esophagus leads into a circular, disk-shaped, central stomach which gives rise to 16 radial pouches extending outward in the radii of the senseorgans and tentacles. Each of these pouches gives off a pair of unbranched, curved canals which enter the lappets, but do not form a ring-sinus. There are 16 well-developed strands of radiating muscle fibers in wall of exumbrella adjacent to gastrovascular cavity. These extend outward in the radii of the tentacles and sense-organs, and fork as they approach the bell-margin.

The color is quite variable, sometimes bluish, sometimes slightly yellowish. Exumbrella and mouth-arms sprinkled over with brownish-red nettling-warts, tentacles reddish-purple.

This species is found among the West Indies and Florida Reefs, and in summer it may drift northward in the Gulf Stream so as to appear off the southern coast of New England from July to September.

L. Agassiz, 1860 and 1862 , found that the planulze of this species, as in $P$. noctiluca, develop directly into medusa without going through a sessile scyphostoma stage and without alternations of generations. The planula are set free into the water where each develops into a single medusa. The minute details of the development have been worked out upon Pelagia noctiluca by Metschnikoff, 1886 (Emb. Stud. an Medusen, Wien.), and by Goette, 1893 (Zeit. für wissen. Zool., Bd. 55, pp. 659-692). The gastrula is formed by invagination. The first pair of radial stomach-pouches appear, according to Goette, as outpocketings from the entoderm and these are quickly followed by another pair from the ectoderm of the throattube, the two latter being $90^{\circ}$ away from the former. The ectodermal pouches then give rise each to two side branches and soon thereafter the entodermal do the same. Thus the central stomach comes to have 12 radial pouches. 4 more radial pouches are soon formed from the ectodermal pouches, so that the young medusa finally possesses 16 radial pouches. It follows in adult medusa that the center of the exumbrella side of the central stomach is derived from entoderm. 2 diametrically opposed, perradial pouches a re ectodemal in origin and the other 2 are entodermal. The 4 interradial pouches are ectodermal, and of the 8 adradial pouches, 4 are ectodermal and + entodermal. The wall of the œsophagus is of ectodermal origin. The young medusa soon develops 8 lobes which bifurcate, giving i 6 marginal lappets. The 8 marginal sense-organs develop before the tentacles. The mouth is at first a simple, round opening at the center of the crater-like ectodermal depression. It soon acquires 4 lips, but the mouth-arms do not develop until a later stage. It is probable that the ectoderm does not take so large a share in the formation of the stomach-pouches as Goette supposes (see Chrysaora and Aurellia). 


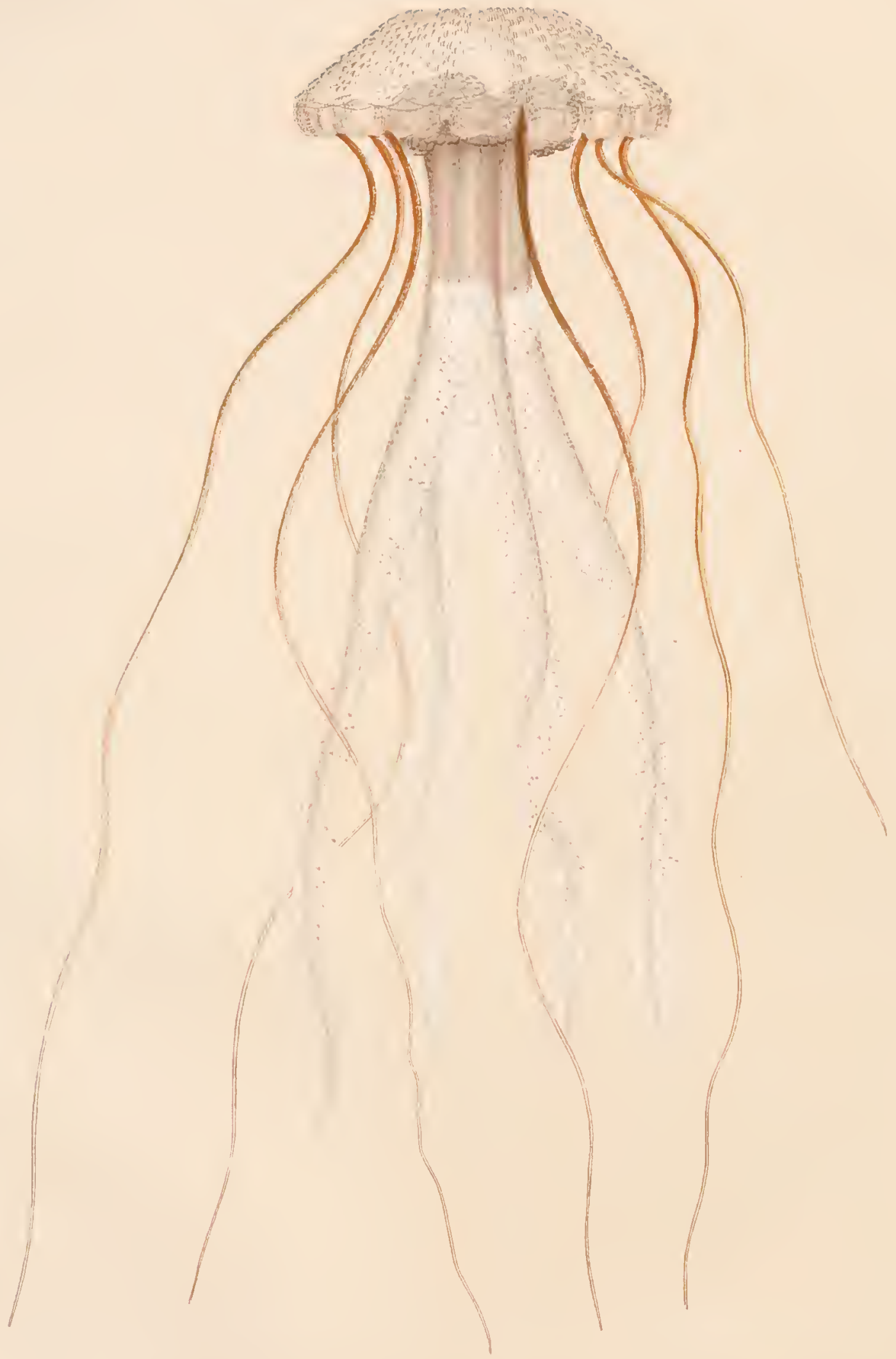

Pelagia cyanella, from the borders of the Gulf Stream off Woods Hole, Massachusetts. Drawn from life, by the late l'ruf. William $\mathrm{K}$. Bronks 

Genus DACTyLOMETRA L. Agassiz, 1862.

Dactylometra quinquecirrha L. Agassiz.

Pelagia quinquecirrha, Desor, E., 1848 , Proc. Boston Soc. Nat. Hist., vol. 3, p. 76.

Dactylometra quinquecirrha, Agassiz, L., 1862, Cont. Nat. Hist. U. S., vol. 4, pp. I25, I66.-Agassiz, A., 1865 , North Amer. Acal., p. 4 8, fig. 69.-Hakckel, isso, Syst. der Medusen, p. 518.-Fewkrs, 1882, Bull. Mus. Comp. Zool. at Harvard College, vol. 9, No. \$, p.293, plate 1, figs. 25-28, 38, 39.-Bicklow, i 89o, Johns Hopkins Univ. Circulars, vol. 9, No. 80, p. 65.-Agassiz, A., and Mayer, 1898 , Bull. Mus. Comp. Zool. at Harvard College, vol. 32, p. I, plates 1-11, 33 figs.Hargitt, 1924, Bull. U. S. Bureau of Fisheries, vol. 24, p. 69, plate 7, fig. 2.- Hargitr, 1905, Journal Exper.Zool., vol. 2, p. 575 (variations).-Vanhöfren, 1906, Nordisches Plankton, Nr. 11, p. 50, fign. $13^{-1} 4$.

Bathyluca solaris (damaged and regenerating specimen?), Marer, rgoo, Bull. Mus. Comp. Zool. at Harvard College, vol. 37 , p. 2, plate I.

Chrysaora, Bıgelow, R. P., I880, Johns Hoplins Univ. Circulars, vol. 9, No. 8, p. 66 (brackish-Water variety from Chesapeake Bay).

Adult medusa.-Bell nearly hemispherical, i7o to Igo mm. in diameter. Numerous small, wart-like clusters of nematocysts thickly scattered over the exumbrella, especially abundant at aboral apex where they appear as little hemispherical projections above the general surface; near the margin they are elongate in shape, while at the margin itself they are again hemispherical as at the apex. 8 marginal sense-organs, 40 tentacles, and 48 marginal lappets. The marginal sense-organs are set within niches between the lappets, 4 being perradial in position and 4 interradial; these niches are procected above by a small web between the lappets. A ciliated, pit-like depression extends downward from the surface of the exumbrella immediately above each sense-organ. The sensory-club projects slightly downward and contains a distal, entodermal mass of crystalline concretions but no ocellus. The entodermal core of the sense-club is hollow and its lumen is connected with the general gastrovascular space of the medusa.

There are 5 tentacles between each successive pair of sense-organs. 3 of these tentacles, the primary and secondary, arise from the clefts between the lappets, but the other 2 (tertiary) are generally found to spring from the under or subumbrella side of the ocular lappets; for even in very large medusx the ocular lappets exhibit but a slight notch adjacent to the tertiary tentacles; in fact, the tertiary tentacles do not usually make their appearance until the medusa is about $130 \mathrm{~mm}$. in diameter and the lappets remain undivided until the medusa is mature, although Hargitt shows that this is subject to great individual variability. Thus in immature medusæ of large size there are usually but 24 tentacles and 32 marginal lappets, and the animal is in the "Chryscora stage." I believe, also, that they often mature in this stage and never reach the Dactylometra condition.

The primary and secondary tentacles are very long and flexible while the tertiary tentacles are only a few millimeters in length. In like manner the lappet-clefts of the primary and secondary tentacles are deep and the lappets almost as long as they are broad; whilc the lappet clefts of the tertiary tentacles are mere shallow notches in the contour of the lappets adjacent to the sense-organs. Mouth-opening cruciform, in center of subumbrella, at extremity of a 4 -cornered cesophagus and surrounded by 4 mouth-arms or palps, which when fully extended are about 3 or 4 times as long as the bell-diameter. The $\delta$ free edges of the moutharms are complexly crinkled and highly flexible. The central stomach occupies a wide lenticular space in the midst of the bell and gives rise to 16 simple, radiating pockets, $S$ in the tentacular and 8 in the rhopalar radii. These pockets are completely separated one from another by 16 radiating septa which join the upper and lower walls of the umbrella cavity together. The tentacles are hollow throughout the greater part of their length and their entoderm is ciliated as is that of the stomach itself.

The gonads are contained in 4 interradially situated, entodermal infoldings of the wall of the subumbrella, and their position is marked by 4 deeply sunken, subgenital pits. The genital organs are provided with numerous, simple, unbranched gastric cirri which project inward into the stomach-cavity. There are two sets of radial muscle-fibers; the principal set is found in the 16 septa between the gastric pouches, and alternating with these in position are 16 strands in the exumbrella, $S$ of which lead outward to the sense-organs and 8 to the primary tentacles.

Color quite variable. In some individuals the disk is pink, in others yellow with a bluish opalescence. The exumbrella is thickly sprinkled with yellow-ocher colored nettlingwarts and there are 16 radiating stripes of reddish color upon the exumbrella in the radii of 
the septa of the peripheral stomach. These reddish stripes extend about half-way from the bell-margin toward the center of the exumbrella and are due to highly refractive, rosincolored pigment granules within the epithelial cells of the disk. The male gonads are generally pink, while the ovaries are yellowish or ashy-gray. The radial muscle-strands of the subumbrella are of a glistening white and the entodermal cores of the tentacles are pink. The mouth-arms are pink or yellow and always sprinkled over with red-colored pigment spots. The marginal sense-organs contain each a mass of glistening white concretions, but no ocelli.

This species extends from the southern coast of New England to the tropics. In August it is abundant in Tampa Bay, Florida. It has been taken by Bickmore at the Bermudas, and by Drayton between the Bermudas and the Azores. "A well-marked southern variety"

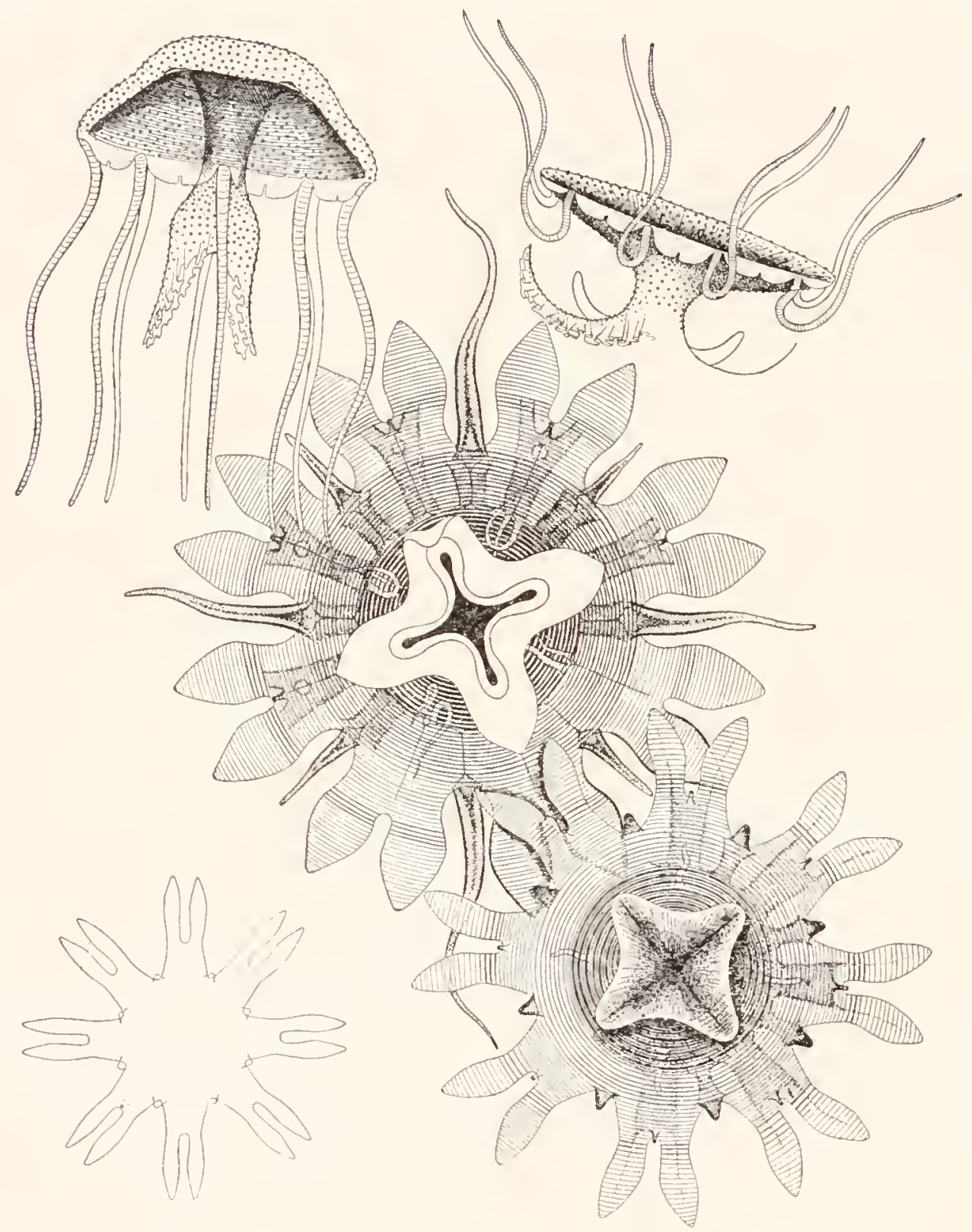

F16. 372.- Young eplyra of Dactlometra quinguecirma. Figures dramn by the late Prof. William K. Brooks at the Chesapeake Bay Laboratory of the Johns Hopkins University. Presented by the Department of Biology of the Johns Hopkins University for publication in this work. 
was found by Brooks at Beaufort, North Carolina, and is figured in plate 64A. It makes its appearance upon the surface along the coast of New England in August when large medusx are found. The young rarely come to view, but remain in deep water.

Varieties and development.-The egg develops into a free-swimming planula which soon attaches itself to the bottom and develops into a scyphostoma having normally 4 tentacles. R. P. Bigelow, I880, states that the so-called "Chrysaora" of the Chesapeake, which is only a brackish-water, abortive variety of Dactylometra, develops from an ephyra through a Pelagia stage, wherein it has only $\&$ tentacles and 16 lappets, and Brooks has figured the ephyrx in the text figures here shown.

The present writer found considerable numbers of Chrysaora-like medusæ in Hampton Roads and Norfolk Harbor, Virginia, and in St. Mary's River, Maryland, early in November, I904 and I905. These were generally pale milky-yellow in color and lacked the rich brown pigment and the 16 pigmented, radial areas seen upon the exumbrella of Dactylometra quinquecirrha. Others had a red-brown spot at the apex of the exumbrella, and surrounding this was a star-like zone of red-brown streaks with pointed ends directed outward. The axial ribs of the mouth-arms (palps) were red-brown. Although all were in the Chrysaora condition and had only 3 tentacles and 4 lappets in each octant, some appeared to be fully mature or with gonads nearly ripe. The exumbrella surface and the palps were covered with dull milky-yellow chusters of nematocysts. There were 8 marginal sense-organs as in Dactylometra, but only 24 tentacles and 32 marginal lappets. None of the medusæ were, however, as large as is commonly seen in full-grown Dactylometra quinquecirrha, the largest Chrysaora-like medusa seen in Norfolk harbor being only $105 \mathrm{~mm}$. in diameter. It should be borne in mind that $D$. quinquecirrha does not usually attain 48 marginal lappets and 40 tentacles until the medusa is $120 \mathrm{~mm}$. in diameter, and it seems therefore that the so-called Chrysaora of the Chesapeake is only a stunted Dactylometra which hecomes mature in the Chrysaora stage, and its pale coloration may be a local peculiarty due to unfavorable conditions of confinement in brackish water. In the purer ocean water at the mouth of Chesapeake Bay the medusc develop into the Dactylometra condition with to tentacles. These conditions are also found in Narragansett Bay, Rhode Island, where in relatively pure clean water the medusa have 40 tentacles, but in brackish estuaries they often become mature with only 24 tentacles and are pale in color.

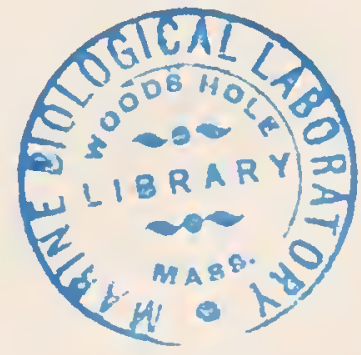







